\title{
Deglacial and postglacial paleoseismological archives in mass-movement deposits of lakes of south-central Québec
}

\author{
Annie-Pier Trottier \\ Centre d'études nordiques (CEN), Québec-Océan (QO) and Département de géographie, Université Laval, \\ QC, Canada \\ (514) 979-0474 \\ annie-pier.trottier.1@laval.ca \\ Patrick Lajeunesse \\ Centre d'études nordiques (CEN), Québec-Océan (QO) and Département de géographie, Université Laval, \\ QC, Canada \\ Patrick.Lajeunesse@ggr.ulaval.ca
}

\begin{abstract}
Alexandre Normandeau ${ }^{1}$
Centre d'études nordiques (CEN) and Département de géographie, Université Laval, QC, Canada

Antoine Gagnon-Poiré2

Centre d'études nordiques (CEN) and Département de géographie, Université Laval, QC, Canada
\end{abstract}

${ }^{1}$ Geological Survey of Canada (Atlantic), Dartmouth, Nova Scotia, Canada

Alexandre.normandeau@canada.ca

${ }^{2}$ Institut national de recherche scientifique, Centre Eau Terre Environnement, Québec, Qc, Canada Antoine.Gagnon-Poire@ete.inrs.ca 


\section{ABSTRACT}

2 Investigation of seismic activity in eastern Canada is important for natural hazard

3 management since two major active seismic zones with many historical records are located

4 in the region: the Western Québec and the Charlevoix-Kamouraska seismic zones, with the

5 latter being the most active in northeastern America. This paper describes and analyses a

6 dataset of high-resolution swath bathymetric imagery, sub-bottom profiles and sediments

7 cores collected in three lakes (Maskinongé, Aux-Sables and St-Joseph) located between two

8 active seismic zones. The geomorphology observed on high-resolution swath bathymetric

9 imagery, the acoustic sub-bottom profiles and the sediment analysis indicate that the lakes

10 were disturbed by three phases of seismically-induced mass-movements since deglaciation :

11 1) during the deglacial Champlain Sea transgression and the rapid initial glacio-isostatic

12 rebound between $\sim 13$ and $10.5 \mathrm{ka}$ cal. BP; 2) around $1180 \mathrm{AD}$; and 3) the well documented

13 CKSZ 1663 AD M>7 historical earthquake. The second phase of earthquake events (1180

14 AD) corresponds chronologically to a previously documented large-landslide in western

15 Québec, dated at $\sim 1020$ yr BP. This earthquake is responsible for remobilizing the largest

16 volume of sediments in the entire stratigraphic sequence of Lake Maskinongé, the

17 westernmost lake. This earthquake was not recorded in Lake Aux-Sables and St-Joseph,

18 which are located eastward from Maskinongé, but the largest MMDs are associated with the

19 well-known 1663 AD event of eastern Québec. Therefore, both earthquake events are

20 interpreted to have different epicenters and the lakes of southeastern Québec recorded

21 earthquakes from both seismic zones.

22 Key words: Mass-movement deposits, earthquakes, lakes, geomorphology, stratigraphy 


\section{INTRODUCTION}

24 The record of seismic activity prior to colonisation is poorly documented in northeastern

25 North America, as historic testimonials are limited to the past $\sim 450$ years (at best) and data 26 availability is closely linked to the locations of historical European settlements (Gouin, 2001).

27 Since the early $20^{\text {th }}$ century, geological investigations and instrumental monitoring systems 28 improved the understanding of seismic activity, providing valuable information on 29 magnitude, location and recurrence intervals of earthquakes (e.g., Lamontagne, 1987; Adams 30 and Basham, 1989). However, only limited information is presently available on pre31 colonization seismic events, even though it is critical for determining the recurrence interval 32 of large infrequent earthquakes (St-Onge et al., 2004; Locat, 2008).

33 Lacustrine basins are depositional environments that can provide detailed information on 34 significant earthquake events (Sims, 1975; Doig, 1986; Shilts and Clague, 1992; Ouellet, 35 1997; Chapron et al., 1996, 1999; Schnellmann et al., 2002; Nomade et al., 2005; Strasser et 36 al., 2006; Arnaud et al., 2007; Chapron et al., 2007; Bertrand et al., 2008; Doughty et al., 37 2010a, 2010b; Ledoux et al., 2010; Moernaut and De Batist, 2011; Lauterbach et al., 2012; 38 Brooks, 2013a, 2013b; Doughty et al., 2014; Brooks., 2016; Locat et al., 2016; Lajeunesse et 39 al., 2017; Normandeau et al., 2017). The high water content and the poor consolidation of 40 lacustrine sediments make them sensitive to external disturbance, causing failures (Shilts, 41 1984; Shilts and Clague, 1992). Many mechanisms can trigger slope disturbances and 42 subaquatic mass-movements such as water level fluctuations, wave loading, high 43 sedimentation rates, anthropogenic disturbances and earthquakes (Shilts, 1984; Shilts and 44 Clague, 1992; De Blasio et al., 2004; Cauchon-Voyer et al., 2008; Fanetti et al., 2008; 
45 Duchesne et al., 2010; Normandeau et al., 2013; Smith et al., 2013). Mass-movement 46 deposits (MMDs) in lakes located near active seismic zones can be a proxy to identify Late47 Pleistocene and Holocene earthquakes (e.g., Brooks, 2016). Many factors can link MMDs to 48 a seismological trigger, but the key signature is multiple, synchronous-triggered MMDs 49 (Shilts and Clague, 1992; Schnellmann et al., 2002; Bertrand et al., 2008; Smith et al., 2013; 50 Brooks, 2015, 2016).

51 MMDs are common in lakes located within and near active seismic zones of eastern Québec 52 (e.g., Shilts et al. 1992; Ouellet, 1997; Lajeunesse et al., 2008; Doughty et al., 2010a, 2010b, 53 2013, 2014; Locat et al., 2016; Lajeunesse et al., 2017) where they can be present at multiple 54 stratigraphic levels. In southern Québec, postglacial MMDs are observed in lakes located 55 near the CKSZ and are absent in lakes located away from it (Ouellet, 1997), suggesting that 56 they have been triggered by earthquake events. Ouellet (1997) and Lajeunesse et al. (2017) 57 proposed that paleoseismological research in eastern Canada should focus on MMDs 58 occurring outside and away from very active seismic zones to identify high magnitude seismic events and avoid the background noise induced by frequent smaller earthquakes. High-resolution swath bathymetric imagery allows full-bottom coverage of lacustrine basins and provides detailed information on lake-bottom morphology and sedimentary processes such as mass-movements (Locat and Lee, 2002; Hilbe et al., 2011; Strasser et al., 2011;

63 Normandeau et al., 2013; Smith et al., 2013; Hilbe and Anselmetti, 2014). Older deglacial 64 and postglacial MMDs in the stratigraphy can be identified on sub-bottom profiles. An 65 approach combining high-resolution swath bathymetric imagery and sub-bottom profiles can provide valuable information on the spatial distribution of MMDs over an entire lake basin 
67 (e.g., Praet et al., 2016; Lajeunesse et al., 2017). In addition, sediment core data allow dating 68 possibilities through depositional rates and can thus lead to a better understanding of 69 paleoearthquakes.

70 This paper presents a morpho-stratigraphic analysis of three lakes located north of the St.

71 Lawrence River, southern Québec (Canada), within the limits of the former deglacial 72 Champlain Sea. The lakes are located between the WQSZ and the CKSZ (Fig. 1b) and 73 provide insights into the deglacial and postglacial history of paleoseismic activity for the area 74 between the major urban centres of Québec City and Montréal. More specifically, it aims to 75 1) describe the geomorphology and distribution of MMDs in these lacustrine basins; 2) 76 identify the triggering factors of mass-movements; and 3) provide a chronostratigraphic 77 framework for mass-movements in these lakes.

\section{STUDY AREA}

$79 \quad$ Physical setting

80 Lakes Maskinongé, Aux-Sables and St-Joseph, southern Québec (Table 1), are located 81 within the Grenville geological province of the Canadian Shield, where bedrock mainly 82 consists of Precambrian metamorphic and igneous rock (Geological Survey of Canada, 83 2008). During the last glaciation, the lake basins were all covered by the Laurentide Ice84 Sheet (LIS) and were entirely deglaciated by $\sim 13 \mathrm{ka}$ cal. (Occhietti et al., 2011). The small 85 and shallow basins are all located below marine limit $(\leq 210 \mathrm{~m}$ asl in the region) (Parent and 86 Occhietti, 1988; Normandeau et al., 2013, 2017) (Fig. 1b) and were emerged from the sea 87 by $10 \mathrm{ka} \mathrm{cal} \mathrm{BP}$ (Parent and Occhietti, 1988). The lakes were selected for this study because 
88 previous investigations highlighted the widespread occurrence of MMDs on their floors

89 (Ouellet, 1997; Normandeau et al., 2013, 2017).

\section{Table 1}

91 Physical characteristics of the investigated lakes.

Lake Maskinongé is a circle-shaped basin and its main tributary is the Mastigouche River

94 located at the northern end of the lake. Lake Aux-Sables is $5.2 \mathrm{~km}$ long, has a maximum

95 width of $1 \mathrm{~km}$ and is oriented from NE to SW. Its sedimentary input comes from multiple

96 small streams, but there is no major tributary. Lake St-Joseph has a length of $7 \mathrm{~km}$ and a

97 maximum width of $3 \mathrm{~km}$. The lake is composed of two main basins. Its main tributary is the

98 Rivière-aux-Pins that discharges into the northern basin of the lake. The three lakes

99 stratigraphic successions were previously investigated and seven Late-Pleistocene and

100 Holocene units were identified ranging from deglacial marine to postglacial lacustrine

101 sediments (Normandeau et al., 2013, 2017).

\section{Regional seismicity}

103 Eastern Canada is part of a mostly aseismic stable craton with some restricted zones showing 104 seismological activity (Fig. 1a). Three of these zones are partly located in the province of 105 Québec and are all related to the reactivation of the Iapetan rift fault system, known as the 106 St. Lawrence rift system (Adams and Basham, 1989; Tremblay et al., 2013). These three 107 zones are: i) the Western Québec seismic zone (WQSZ), where earthquake epicentres are 108 mostly distributed in eastern Ontario, western Québec and northern New-York state; ii) the 109 Charlevoix-Kamouraska seismic zone (CKSZ), centered in the St. Lawrence Estuary, south 
110 of the Saguenay fjord (Fig. 1), and iii) the Lower St. Lawrence seismic zone (LSLSZ), located

111 in the eastern part of the St. Lawrence Estuary, which has a low activity of small magnitude

112 earthquakes (Adams and Basham, 1989; Locat, 2011). The WQSZ and the CKSZ are also

113 partly due to local crustal fractures resulting from a passage over a hot spot during the

114 Cretaceous and a meteoritic impact structure, respectively (Adams and Basham, 1989). The

115 WQSZ is divided in two areas: a SE-NW band extending from Montréal to the upper

116 Gatineau River and a less active southern band with epicenters located along the Ottawa

117 River (Adams \& Basham, 1989). Many historical earthquakes have been documented in the

118 WQSZ, with events reaching $\mathrm{M}=5$ to $\mathrm{M}=6$ (Fig. 1: 1732 AD, M5.8; 1935 AD, M6.2; 1944

119 AD, M5.8) (Natural Resources Canada, 2018). The CKSZ, southeastern Québec, is the most

120 active seismic zone in eastern Canada (Fig. 1a), with many historical earthquakes reaching

$121 \mathrm{M} \geq 6$ (Fig. 1: 1663 AD, M>7; 1860 AD, M6; 1870 AD, M6.5; 1925 AD, M6.2; 1971 AD,

122 M6) (Lamontagne, 1987; Adams and Basham, 1989; Doig, 1998; Tuttle and Atkinson, 2010;

123 Locat, 2011).

124 The region in which the three studied lakes are located is bounded by the two most important 125 seismic zones of eastern Canada (WQSZ and CKSZ) (Fig. 1a, b), exposing it to a recurrence 126 of seismic events since deglaciation. Although only few historical earthquakes occurred in 127 the WQSZ, analysis of the disturbance of lacustrine sediment has linked deposits in the 128 Outaouais region to the 1935 AD seismic event (Shilts, 1984; Shilts and Clague, 1992; 129 Doughty et al., 2010a, 2010b). Cores analysis from lacustrine basins also allow Doig (1986, $1301991,1998)$ to identify past earthquakes. Additionally, pre-historical seismic events (7060 $131 \mathrm{yr} \mathrm{BP}, 4550 \mathrm{yr}$ BP and $1020 \mathrm{yr}$ BP) from the WQSZ were identified by analysing and dating 
132 large terrestrial landslides (Aylsworth et al., 2000; Brooks, 2013a, 2013b). By contrast, the

$133 \mathrm{CKSZ}$ has an approximate recurrence rate of 70 years for earthquakes of magnitude $\mathrm{M} \geq 6$

134 (Ouellet, 1997; Natural Resources Canada, 2018). Ouellet (1997) observed that the largest

135 sublacustrine disturbances occurred usually within a radius of $34.5 \pm 5 \mathrm{~km}$ from the CKSZ.

136 Physical damage to infrastructures has also been reported in the literature at a distance of 180

$137 \mathrm{~km}$ to over $800 \mathrm{~km}$ from the epicenter of an earthquake of magnitude $\geq 7$ (Ouellet, 1997;

138 Geological Survey of Canada, 2001). Deglacial and postglacial seismic events were also

139 identified by Tuttle and Atkinson (2010) dated at 10.12-9.41 ka yr BP and 5.04 ka yr BP in

140 the Charlevoix region, and an event around $7.25 \mathrm{ka}$ yr BP was dated by Cauchon-Voyer

141 (2008) in the St. Lawrence Estuary.

\section{MATERIAL AND METHODS}

143 Hydroacoustic survey

144 Hydroacoustic surveys were undertaken in the three lakes between 2011 and 2014 to acquire

145 high-resolution swath bathymetry imagery and sub-bottom profiles. The hydroacoustic 146 database presented in this paper is the same as the one used by Normandeau et al. (2013, 147 2017). Data was acquired using two different swath bathymetric systems, depending on lake 148 depth and accessibility. In the shallow southern basin of Lake St-Joseph $(<20 \mathrm{~m})$, data was 149 acquired with an Odom ES3 multibeam echosounder $(240 \mathrm{kHz})$, together with an Ixsea 150 Octans III motion sensor and an SX Blue DGPS ( $\sim 60 \mathrm{~cm}$ precision). The other lakes were 151 mapped with a GeoAcoustics GeoSwath Plus Compact interferometric bathymetric sonar $152(250 \mathrm{kHz})$, coupled with a Valeport SMC motion sensor and a Hemisphere V101 DGPS ( $15360 \mathrm{~cm}$ precision) for positioning. The instruments were mounted on two different platforms; 
154 an inflated boat (Zodiac) and a pontoon boat. Bathymetric data were post-processed using

155 Caris Hips and Sips 8.1 software.

156 Acoustic stratigraphy data was acquired using a dual frequency Knudsen 3212 (3.5 and 12 $157 \mathrm{kHz}$ ) sub-bottom profiler; refer to Figures 3A, C, D of Normandeau et al. (2017) for the 158 profiling survey pattern. Survey lines were planned perpendicularly to each other in order to 159 better visualize the distribution of the acoustic units in the lake basins. A sound velocity of $1601500 \mathrm{~m} \mathrm{~s}^{-1}$ was used to compute depths and sediment thickness. The SegyJp2Viewer software 161 from Natural Resources Canada (NRCan) and SonarWiz 5.0 were used to analyze the sub162 bottom profiles which were then coupled to the high-resolution bathymetric imagery using 163 the QPS Fledermaus software.

\section{Sedimentological analysis}

165 Short cores $(<1.5 \mathrm{~m}$; Table 2$)$ were collected with a percussion corer from an ice surface 166 during winter at all of the studied lakes. Based on the sub-bottom profile dataset, one coring 167 site in each lake was chosen to sample recent undisturbed sediments to get a deposition rate 168 through ${ }^{210} \mathrm{~Pb}$ radiometric activity. Cores were analyzed through a CT-Scan at the Institut 169 National de la Recherche Scientifique Centre Eau Terre Environnement (INRS-ETE) in 170 Québec City and then split, visually described and photographed. Magnetic susceptibility 171 (MS) was measured manually every centimeter using a Bartington MS3.

172 Samples were collected in cores at every centimeter on the upper $15 \mathrm{~cm}$ for ${ }^{137} \mathrm{Cs}$ and ${ }^{210} \mathrm{~Pb}$ 173 radiometric analyses. The sedimentation rates (SR), assuming a constant rate, were calculated 174 using: 


$$
\mathrm{SR}=-\left[\left(\ln (2) /\left(\text { Slope }^{*} 22.3\right)\right]\right.
$$

176 (e.g., Gagné et al., 2009; Duboc et al., 2016). No samples from a depth deeper than where 177 the non-supported ${ }^{210} \mathrm{~Pb}$ activity values reach the supported ${ }^{210} \mathrm{~Pb}$ activity values were used 178 to calculate each respective sedimentation rates. On the other hand, the radiometric activity 179 of ${ }^{137} \mathrm{Cs}$ allowing sediment deposited in $1963 \mathrm{AD}$ to be identified by the peak activity of ${ }^{137} \mathrm{Cs}$ 180 attributed to the atmospheric nuclear bomb testing (Arnaud et al., 2002). Radiometric activity 181 was measured on every samples at the Laboratoire de Radiochronologie of the Centre 182 d'études nordiques (U. Laval).

\section{Table 2}

184 Description and location of cores collected in the investigated lakes.

\section{RESULTS}

\section{Lake bottom morphology}

188 High-resolution swath bathymetric imagery reveals similar morphologies on the lake basin

189 floors at all three lakes: headwall scarps, gullies, lobe of hummocky debris and hummocky 190 topographies (Fig. 2). These morphologies are typical of lacustrine basins affected by mass191 movements (e.g., Hampton and Locat, 1996; Moernaut and De Batist, 2011). These 192 observations are also coherent with results of previous studies that highlighted that the 193 studied lakes are affected by mass-movements (Ouellet, 1996; Normandeau et al., 2013, 194 2017). Therefore, the above morphological criteria (Fig. 2) are here used to identify MMDs 195 on the high-resolution swath bathymetric imagery. 
197 For the purpose of this study, the seven acoustic units previously identified in the three lakes 198 by Normandeau et al. $(2013,2017)$ have been grouped into three main depositional units, 199 providing a stratigraphic framework (Fig. 3). Ua located at the bottom of the stratigraphic 200 sequence lacks acoustic penetration and is interpreted as ice-contact sediments (till) or 201 bedrock. Ub is a thick acoustically transparent unit overlaid by high amplitude parallel 202 reflections and groups U3 and U4 of Normandeau et al. (2013). This unit results from the 203 high sedimentation rates of the glaciomarine environment of the Champlain Sea during rapid 204 ice margin retreat (Normandeau et al., 2013). Uc has low amplitude parallel reflections and 205 is associated with paraglacial and postglacial sedimentation; it groups U5, U6 and U7 of 206 Normandeau et al. $(2013,2017)$.

207 These three units are observed in Lake Aux-Sables and Lake St-Joseph, but the acoustic 208 attenuation in the sediments limited the signal penetration down to Ua in Lake Maskinongé. 209 However, Ub and Uc are identified in every investigated lake. MMD acoustic facies is 210 observed in Ub and Uc: it is acoustically transparent to chaotic, has a hummocky topography, 211 an erosive base and a lense geometry (Fig. 3).

\section{Lake Maskinongé}

213 The high-resolution bathymetric map of Lake Maskinongé (Fig. 4a) reveals three distinct 214 types of lake floor morphologies (Fig. 4b): 1) a flat smooth surface; 2) linear to sinuous 215 structures from 50 to $100 \mathrm{~m}$ wide and $\sim 600 \mathrm{~m}$ long, appearing slightly shallower $(\leq 1 \mathrm{~m})$ and 216 in topographic unconformity with the flat bottom floor; and 3) widespread mass-movement 217 surface morphologies, such as hummocky topography, displaced blocks, scarps on the 
218 southeastern margins and lobes of hummocky debris extending away from the lateral slopes.

219 The linear to sinuous structures all converge towards the deep basin and are located on the

220 northern slope at the front of the Mastigouche River mouth. MMDs are all coalescent,

221 forming one large-scale chaotic area on the lake bottom, covering the base of the western, 222 southern and eastern slopes of the lake (Fig. 4b). MMD morphologies cover $4.09 \mathrm{~km}^{2}$, which 223 represents $40 \%$ of the lake basin surface.

224 The sub-bottom profiles show the acoustic facies of the deposits underlying the topographic morphologies (Fig. 5). Below the smooth flat bottom floor lies $4 \mathrm{~m}$ of continuous parallel 226 reflections (Uc). Sub-bottom profiles show a lateral unconformity under the morphological 227 linear to sinuous structures where the parallel reflections are acoustically chaotic and 228 vertically offset. Lenses of acoustically chaotic sediments associated with MMD facies are 229 visible at three different intervals within the acoustic sequence. These lenses are observed at 230 depth of 5.5-6.0 m (Event ME1 within Ub), $1.5 \mathrm{~m}$ (Event ME2 within Uc) and 0.5-1.0 m 231 (Event ME3 within Uc), indicating three distinct mass-movement events. The acoustic 232 attenuation in the sediment made it impossible to delineate the base of the first and second 233 deposit of mass-movement on all of the sub-bottom profiles. In this case, MMDs overly 234 directly the acoustically transparent glaciomarine unit (Ub). However, ME2 deposit underlies 235 the extensive hummocky topography observed on the swath bathymetric imagery (Fig 6), as 236 ME3 is associated with small MMD lenses located only at the base of slopes. Based on the 237 sub-bottom profiles where the bottom of ME2 is observed, the deposits ME2 and ME3 reach 238 a maximal thickness of $7 \mathrm{~m}$ and $1.5 \mathrm{~m}$, respectively. The isolated displaced blocks are 239 characterized on sub-bottom profiles by high-amplitude parallel reflections and sharp vertical 
240 sidewalls. The displaced blocks rise up $4.5 \mathrm{~m}$ above the MMDs (Fig. 5b) and the parallel

241 reflections indicate that they are areas of remnant sediments not displaced by mass-

242 movements.

243 At a location selected from the analysis of the sub-bottom profiles, a short core (MAS15-

244 1aP), $105 \mathrm{~cm}$ long, was collected at a strategic undisturbed location in Uc (Fig. 7). Structures

245 caused by the freezing of the sediment during core collection appear as black areas on the

246 CT-Scan images. ${ }^{210} \mathrm{~Pb}$ profile of Lake Maskinongé is non-linear and the values between the

247 depth of $6.25 \mathrm{~cm}$ and $8.25 \mathrm{~cm}$ are probably related to a rapid sedimentation event and were

248 excluded from the calculation of the depositional rate (Fig. 8). The peak activity of ${ }^{137} \mathrm{Cs}$

249 measured in the core is observed at a depth of $7.25 \mathrm{~cm}$, while the ${ }^{210} \mathrm{~Pb}$ radiometric activity

250 reveals a depositional rate of $0.18 \mathrm{~cm} \mathrm{yr}^{-1}$ (Fig. 8). The depositional rate obtained by the ${ }^{210} \mathrm{~Pb}$

251 radiometric dating methods is in good agreement with ${ }^{137} \mathrm{Cs}$ peak activity. A layer (ML1)

252 with high CT-numbers values is observed in the upper part at a depth of $8.5 \mathrm{~cm}(\sim 12 \mathrm{~cm}$

253 thick) and also corresponds to high MS values (Table 3, Fig. 7). Such high values indicate a

254 detrital source of sediment rather than organogenic material. According to the calculated

255 depositional rate, the layer ML1 is dated at 1969 AD.

256 Table 3

257 Depth, thickness and date of the layers observed in each core.

258

259 Lake Aux-Sables

260 Analysis of the high-resolution swath bathymetric imagery of Lake Aux-Sables (Fig. 9a)

261 reveals two main types of lake bottom morphologies (Fig. 9b): 1) a smooth lake bed surface, 
262 present on the flat basin floor and on the slopes; and 2) the widespread occurrence of MMD 263 surface features in the basin. The smooth lake bed surface is observed in southeastern and 264 northern sectors of the lake. MMD features are mostly concentrated in the south-central 265 sector of the lake, but a few small isolated morphologies are also observed in its northern 266 sector. MMD structures are located at the base of the slopes and are characterized by a 267 hummocky topography. Headscarps and gullies are typical morphologies observed on the 268 lake slopes (Fig. 10). Lobes of hummocky debris are also splayed from the lateral sidewalls 269 onto the central basin. MMD surface morphologies cover $1.8 \mathrm{~km}^{2}$, representing $35 \%$ of the 270 lake surface.

271 Sub-bottom profiles (Fig. 11) show an uppermost unit (Uc) acoustically transparent on the 272 lake lateral shelves, as MMDs facies are observed in the deep basin (Event SE1 within Uc). 273 Uc has a smooth topography and drapes the underlying glaciomarine unit (UB) conformably, 274 while MMDs facies has a hummocky topography and a sharp erosive contact at its base. 275 MMDs of the event SE1 reach a maximum thickness of $5 \mathrm{~m}$ on the sub-bottom profiles. No 276 sediment apparent on the sub-bottom profileare observed over the MMDs of event SE1, 277 suggesting that the MMDs are modern in age or have the same acoustic signature as the 278 overlying gyttja deposit.

279 A sediment core (LAS15-1P), $131 \mathrm{~cm}$ long, was collected in Lake Aux-Sables in the 280 undisturbed Uc (Fig. 7). ${ }^{210} \mathrm{~Pb}$ profile of Lake Aux-Sables is non-linear due to biological 281 mixing at the surface (Fig. 8). Thus, the two surficial values were excluded from the 282 calculation of the sedimentation rate. The ${ }^{210} \mathrm{~Pb}$ radiometric activity reveals a depositional 283 rate of $0.08 \mathrm{~cm} \mathrm{yr}^{-1}$, which is in general agreement with the peak activity of ${ }^{137} \mathrm{Cs}$ observed 
284 at a depth of $5.75 \mathrm{~cm}$ (Fig. 8). Layers of high CT-numbers values are observed at a depth of $2855.5 \mathrm{~cm}(\mathrm{SL} 1), 23 \mathrm{~cm}$ (SL2) and $35 \mathrm{~cm}$ (SL3) in LAS15-1P, with a respective thickness of 4.5 $286 \mathrm{~cm}, 5.5 \mathrm{~cm}$ and $6 \mathrm{~cm}$ (Table 3, Fig. 7). Such depths suggest a deposition of the detrital layers 287 around 1947 AD (SL1), 1785 AD (SL2) and 1704 AD (SL3); note that the thickness of the 288 layers was subtracted from the depth to calculate the ages. The MS in core LAS15-1P is 289 highly variable and only the second layer of high CT-number values (SL2, $23 \mathrm{~cm}$ ) 290 corresponds to a small increase of MS.

291 Lake St-Joseph

292 The northern and southern basins of Lake St-Joseph are isolated from each other by a 2-m 293 deep central sill (Fig. 12a, b); both have distinct morphologies and bathymetries. The 294 southern basin has a flat and uniform shallow lake bottom morphology $(\leq 12 \mathrm{~m})$; the northern 295 basin is deeper $(\leq 37 \mathrm{~m})$ with widespread MMD surface morphologies. Mass-movement 296 morphologies observed on the bathymetry imagery include headscarps, residual mounds, 297 hummocky topography and compression ridges caused by frontal thrusting (Fig. 12b, 13). 298 The hummocky areas of MMDs in the northern basin originated from the northeastern, 299 southern and eastern slopes and coalesce on the basin-floor. They cover $2.8 \mathrm{~km}^{2}$, representing $30036 \%$ of the basin surface.

301 Three different stratigraphic levels of MMDs are observed on the sub-bottom profiles in Ub 302 and Uc, indicating distinct mass-movement events (Fig. 14). Two stacked transparent to 303 chaotic lenses (MMD Facies) are observed in a topographic depression at the base of the 304 western slope, buried under $5.5 \mathrm{~m}$ of sediments (Events JE1 \& JE2 within Ub). A third 305 acoustically transparent to chaotic lens associated with MMD facies is located at the base of 
306 the eastern slope (Event JE3 within UC). This thick $(\leq 10 \mathrm{~m})$ lens underlies hummocky

307 topography and has a sharp erosive base. The interface between the uppermost MMDs (JE3)

308 and $\mathrm{Ub}$ is characterized by a high-amplitude acoustic reflection. Compression ridges

309 associated with frontal thrusting are located at the distal part of MMDs. These ridges make a

310 lateral transition between MMDs facies and the undisturbed acoustically laminated Uc. The

311 thick JE3 MMD is covered by 0.5-1.0 m of sediment (Fig. 14a, c).

312 Core LJS15-1bP, $123 \mathrm{~cm}$ long, was collected in the northern basin in an undisturbed sector

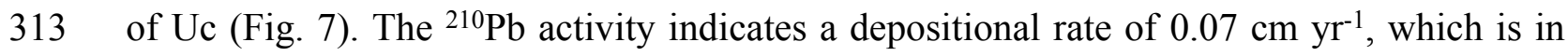
314 good agreement with the ${ }^{137} \mathrm{Cs}$ activity at a depth of $3.25 \mathrm{~cm}$ (Fig. 8). Layers of high CT315 number and MS values are observed at a depth of $19 \mathrm{~cm}$ (JL1) and $49 \mathrm{~cm}$ (JL2), with a 316 respective thickness of $3.5 \mathrm{~cm}$ and $1 \mathrm{~cm}$ (Table 3, Fig. 7). According to the depositional rate, 317 these layers are dated at 1745 AD (JL1) and 1366 AD (JL2).

\section{DISCUSSION}

\section{Seismicity as a trigger of mass-movements}

320 Sediments of the three lakes show evidence of mass-movements that, in terms of area and 321 volume, mostly affected the late-deglacial and postglacial units (Uc: ME2, ME3, SE1 \& JE3), 322 although buried MMDs were observed in the glaciomarine unit (Ub: ME1, JE1 \& JE2) 323 deposited during deglaciation. Even though the basins are all located within the area of two 324 active seismic zones and are all widely affected by mass-movements, it is necessary to 325 consider every possible trigger mechanism before concluding to a seismic trigger.

326 High water level variations can trigger slope failures. In the studied area, such variations 
327 were limited to the deglacial Champlain Sea transgression and forced regression (from 11.1 328 cal. Ka BP to 10.5 cal. ka BP) (Occhietti and Richard, 2003), and no major water level 329 fluctuation occurred since the establishment of the postglacial drainage network. 330 Additionally, in contrast to open sea water, lacustrine environments are not subject to high 331 wave energy on shoreline. The studied lakes also have a relatively small surface area (from $3325.2 \mathrm{~km}^{2}$ to $11.3 \mathrm{~km}^{2}$ ) reducing the fetch and the possibility to generate strong erosive waves. 333 Therefore, the modern-aged MMDs observed in Uc were most probably not triggered by 334 major water level variations or wave loading on the shoreline. Conversely, it is not excluded 335 that the MMDs observed within the glaciomarine unit (Ub) could have been triggered by a 336 major water level variation although wave loading would be unlikely since the basins were 337 situated in isolated bays during the regression.

338 The MMDs surface morphologies observed on the swath bathymetric imagery indicate that 339 the disturbed slopes of Lake Maskinongé are not connected to sectors receiving a higher 340 sedimentary input. In fact, the disturbed slopes are located on the opposite side of the lake, 341 whereas the slopes located at the river mouth are the only ones that do not show scarps or 342 MMDs. Lake Aux-Sables disturbed slopes are also not associated with a high sedimentation 343 rate, having no main river input but many small streams instead. The northern basin of Lake 344 St-Joseph is also widely affected by mass-movements but, even though scars are observed 345 on the swath bathymetric imagery near the river discharge, the disturbed area extends far 346 from the delta. However, the surface features observed on the swath bathymetric imagery are 347 only relevant to the modern-aged events. In the studied lakes, late postglacial slope failures 348 deposited within Uc are not associated with an overload resulting from high depositional 
349 rates near a river discharge because 1) the majority of the disturbed slopes observed on the 350 swath bathymetric imagery are located far from deltas and 2) the lakes are all characterized 351 by modern low depositional rates (from $0.07 \mathrm{~cm} \mathrm{yr}^{-1}$ to $0.18 \mathrm{~cm} \mathrm{yr}^{-1}$ ). However, overloading 352 is not excluded as a trigger for the buried MMDs observed within the glaciomarine unit (Ub: 353 ME1, JE1 \& JE2), since 1) deglacial times were characterized by higher sedimentation rates 354 (Normandeau et al., 2013, 2016) and 2) the setting of each lake was different at that time, 355 being deeper basins during the Champlain Sea transgression and having different location of 356 sedimentary input.

357 From the analysis of the swath bathymetric imagery, MMDs are widespread in the lake basins: 358 they extend over a total of $34 \%$ to $40 \%$ of the surface of the three lakes. According to the 359 high-resolution swath bathymetric imagery and the acoustic sub-bottom profiles analysis, 360 synchronous events occurred within each lake respectively: headwall scarps are observed on 361 different slope orientations and many MMDs are observed within the same stratigraphic unit. 362 The MMDs of events ME2, SE1 and JE3 corresponding to widespread disturbed topography 363 on the lake floors indicate that synchronous events triggered the slopes failures of more than 364 one sidewall and formed one large-scale coalescent MMD or many isolated smaller MMDs 365 in each respective lake. The MMDs of event ME3 do not cover a wide surface area, but are 366 observed at the base of many slopes indicating that small synchronous failures occurred.

367 Based on the synchronicity of multiple mass-movements (e.g. Schnellmann et al., 2002; 368 Fanetti et al., 2008; Doughty et al., 2010b) and considering that the lakes are all located 369 within the area of two active seismic zones, mass-movements events ME2, ME3, SE1 and 370 JE3 are interpreted to be seismically induced. Similarly, in situ disrupted horizontal parallel 
371 reflections within a particular layer have been attributed to liquefaction induced by a nearby 372 strong seismic shaking (Shilts et al., 1992; Beck, 2009; Tuttle and Atkinson, 2010). The linear

373 to sinuous structures observed on the swath bathymetric imagery and on acoustic subbottom

374 profiles at the Mastigouche River mouth in Lake Maskinongé are interpreted as liquefaction 375 features since sub-bottom profiles show lateral uncomformity in the acoustic draping parallel 376 reflections indicating that the sediments were fluidilized in situ (Shilt et al., 1992). These 377 disrupted reflections in upper Uc suggest that a strong modern-aged earthquake might have 378 disturbed the sedimentary infill in Lake Maskinongé. However, other possible aseismic 379 triggers are still considered for the deglacial mass-movement events ME1, JE1 and JE2 since 380 depositional environments were highly different at that time.

\section{Deglacial and postglacial seismicity}

382 The stratigraphy and distribution of MMDs in the investigated lakes are here used to 383 reconstruct the history of major seismic events since deglaciation. The ${ }^{210} \mathrm{~Pb}$ depositional 384 rates provided a chronological framework, but the proposed chronology represents a minimal 385 age of the events because: 1) only the upper $15 \mathrm{~cm}$ of sediments were used to calculate the 386 mean depositional rates and then applied to a depth ranges of $0.5-1.5 \mathrm{~m} ; 2$ ) compaction in the 387 sediments occur with time, implying that the ${ }^{210} \mathrm{~Pb}$ radiometric dating overestimates the 388 depositional rates; 3) a mean sound velocity of $1500 \mathrm{~m} / \mathrm{s}$ was used to calculate the time389 travelling depths and no sound velocity correction was applied for the sedimentary column; 390 and 4) measures of depths on the sub-bottom profiles have a precision of $\sim 0.5 \mathrm{~m}$.

391 MMDs in the lakes occur along three distinct stratigraphic levels, indicating three different 392 phases of mass-movements (Fig. 5 \& 14, Table 4): deposits of Phase 1 (ME1, JE1 \& JE2) 
393 are in the glaciomarine unit (Ub), and deposits of phases 2 (ME2) and 3 (ME3 \& JE3) are in

394 the upper part of the paraglacial and postglacial unit (Uc) and are separated by $0.5-1.0 \mathrm{~m}$ of

395 undisturbed sediments. The stratigraphic position of the MMDs of Phase 1 observed in Ub

396 in Lake Maskinongé and St-Joseph indicates a triggering mechanism during the deglacial

397 Champlain Sea probably related to the rapid initial glacio-isostatic rebound (Normandeau et

398 al., 2013; Lajeunesse, 2016). Normandeau et al (2017) also highlighted 9 stacked MMDs

399 buried in Ub in Lake Aux-Sables. Brooks (2016) suggested that seismic activity can be

400 increased during deglaciation due to the crustal deformation during glacio-isostatic rebound.

401 The buried MMDs are probably associated with the same series of diachronic events that

402 took place during the retreat of the LIS margin, according to each lake basin respective timing

403 of deglaciation. A phase of enhance mass-movement events thus likely occurred around 11.1

404 to 10.5 cal. Ka BP, during the deglacial Champlain Sea episode, most probably triggered by

405 local seismic activity caused by the rapid initial glacio-isostatic rebound. However, deglacial

406 times were characterised by depositional environments of higher energy, sedimentation rates

407 and water level variation (Normandeau et al., 2013, 2017), which could also precondition the

408 sediments to slope failures (Lajeunesse and Allard, 2002).

409 The MMD associated to Phase 2 (ME2) is only observed in Lake Maskinongé (Table 4), at 410 a depth of $1.5 \mathrm{~m}$ in the postglacial unit (Uc). The extrapolated ${ }^{210} \mathrm{~Pb}$ depositional rate over 411 the sedimentary column in the Lake Maskinongé indicates that an earthquake occurred 412 around or before 1180 AD. Brooks (2013a) also dated a large-scale terrestrial landslide $(\sim 31$ $413 \mathrm{~km}^{2}$ ) in Quyon Valley, near the WQSZ, at $\sim 1020 \mathrm{yr}$ BP and a minimal magnitude of $\mathrm{M} \sim 6.1$ 414 was estimated. Based on the dating proximity and the intensity of the seismic shock, we 
415 suggest that the MMD associated to Phase 2 (ME2) relates to the same event recorded in

416 Quyon Valley, indicating that a strong earthquake $(M \geq 6.1)$ from the WQSZ disturbed Lake

417 Maskinongé sedimentary sequence around 1020 yr BP. However, Lake Aux-Sables and

418 Lake St-Joseph stratigraphic sequences did not record that event most probably because they

419 are located farther away from the WQSZ (235 km and $290 \mathrm{~km}$, respectively).

420 Similarly, the deposit of the third and last phase of mass-movement (ME3 \& JE3) is observed 421 in the same paraglacial and postglacial unit (Uc) at a depth of 0.5-1.0 $\mathrm{m}$ in Lake Maskinongé 422 and St-Joseph (Table 4). This MMD was cored by Normandeau et al (2013) at a depth of $423 \quad 0.23 \mathrm{~cm}$ in Lake Saint-Joseph and dated with bulk sediment at 1250 AD. However, we revise 424 this date since the correlation between bulk sediment dating and a given MMD can be low 425 and such a depth indicate a timing event around $1685 \mathrm{AD}$ using our new depositional rate of $4260.07 \mathrm{~cm} \mathrm{yr}^{-1}$. According to the depth of the MMDs ME3 \& JE3, it seems unlikely that those 427 events relate to the strong ( $\mathrm{M}$ 6.2) historical earthquake that occurred in $1935 \mathrm{AD}$ in the 428 WQSZ (Doughty et al., 2010b). We rather suggest that the deposits of ME3 \& JE3 are 429 associated with the $\mathrm{M}>71663 \mathrm{AD} \mathrm{CKSZ}$ earthquake, since it was the strongest historical 430 event ever recorded in eastern Canada (Locat, 2002). The MMDs of event SE1 in Lake Aux431 Sables are most probably related to the same earthquake (CKSZ M > 7, $1663 \mathrm{AD})$ since 1) 432 the lake is located between Lake Maskinongé and St-Joseph, which basins recorded the 433 seismic shock, and 2) the highly chaotic topography of Lake Aux-Sables indicates a modern434 aged event. However, it is not clear if the MMDs either are recent or have the same acoustic 435 signature as the overlying gyttja deposit because no sediment apparent on the sub-bottom 436 profile returns are observed over the MMDs. 
Table 4

438 Summarize of the three phases of mass-movements with their respective deposits, date and seismic 439 trigger event.

441 The seismic events reported by Tuttle and Atkinson (2010) dated at 5.04 ka yr BP in the 442 Charlevoix region and the one reported by Cauchon-Voyer (2008) at 7.25 ka yr BP in the St. 443 Lawrence Estuary are not observed in the sedimentary record of the three studied lakes, 444 suggesting epicenters located farther to the east. The pre-historic WQSZ events reported by 445 Aylsworth et al. (2000) dated at $7060 \mathrm{yr}$ BP and $4550 \mathrm{yr}$ BP were not recorded in the 446 stratigraphy of the studied lakes, neither is the strong recent historical earthquakes of the 447 WQSZ (1935 AD, M 6.2).

448 Scale of the deposits

449 The deposits related to Phase 2 in Lake Maskinongé (ME2) represent the main mass450 movement structures in its entire acoustic stratigraphy. The deposits of phase 2 (ME2) is 451 thicker than the deposits of Phase 3 (ME3) (7 m v.s $1.5 \mathrm{~m}$ thick, respectively), even if the 452 earthquake of Phase 2 is believe to be of smaller magnitude than the event of Phase $3(\mathrm{M} \geq$ 4536.1 vs $M \geq 7$, respectively). Conversely, the CKSZ M > 71663 AD event triggered the biggest 454 MMD structures in Lake Aux-Sables (SE1, $\leq 5 \mathrm{~m}$ thick) and in Lake St-Joseph (JE3, $\leq 10 \mathrm{~m}$ 455 thick). It was previously mentioned that Lake Aux-Sables and St-Joseph were not submitted 456 to seismic disturbances during the event of phase 2 of the WQSZ because the lakes are located 457 too far away. The difference of thickness between the deposits of each seismic events indicate 458 that the recurrence rate of strong earthquakes controls the ability of a lacustrine basin to 459 record seismic shaking by reducing the sediment availability to form wide mass-movement 
460 deposits under strong seismic shaking (Wilhelm et al., 2016), in favor of frequent smaller 461 deposits instead. In Lake Maskinongé, MMDs of the event ME3 are much smaller than the 462 MMDs of the event ME2 because the failure that occurred some 600 years earlier reduced 463 the sediment availability to generate a large-scale MMDs. Therefore, MMDs associated with 464 a seismic event are not necessarily representative of the intensity or the proximity of an 465 earthquake because the recurrence interval affects sediment availability. In order to identify 466 the intensity of past earthquakes, investigations need to contextualize the seismically induced 467 MMDs in a regional stratigraphic framework and to consider the recurrence rates of strong 468 earthquakes.

RAPIDLY DEPOSITED LAYERS

470 In contrast with the normal organogenic lacustrine sedimentation, high MS values associated 471 with high CT-numbers values in cores indicate a detrital source of material. These layers are 472 referred here as rapidly deposited layers (RDLs). Similar thin silt layers were observed by 473 Doig (1986) in lakes located in southern Québec and were interpreted to result from the fine 474 grained particles kept in suspension by water oscillation during a sublacustrine mass475 movement. Doig (1986) interpreted the RDL as seismically induced due to the proximity of 476 an active seismic zone and to the absence of organic material near the layers, excluding the 477 possibility of flooding. RDLs are also reported in the Saguenay Fjord and were interpreted 478 as turbidites (St-Onge et al., 2004; St-Onge et al., 2012).

479 In Lake Maskinongé, the RDL ML1 observed at a depth of $8.5 \mathrm{~cm}$ (1969 AD) in core 480 MAS15-1aP could result from a terrestrial 1950 AD mass-movement (ArchivesCanada) that 481 occurred in the glaciomarine silty-clay along the shore of the Mastigouche River, the main 
482 tributary of the lake. RDLs observed in lacustrine basins are thus not systematically 483 associated with an earthquake, even if the lakes are located near active seismic zones as the 484 entire watershed dynamics need to be considered in order to identify the trigger of such layers 485 in a lake basin. Conversely, the RDL SL1 dated at 1947 AD in Lake Aux-Sables could be 486 of seismic origin because two significant earthquakes occurred in the WQSZ during the first 487 half of the $20^{\text {th }}$ century (1935 AD, M 6.1; 1944 AD, M 5.8) (Natural Resources Canada, 488 2018). Similarly, the RDL JL1 in Lake St-Joseph dated at 1745 AD could have been trigger 489 by the WQSZ 1732 AD (M 5.8) event. No historical earthquakes seem to relate to the RDLs 490 SL2 and SL3 in Lake Aux-Sables and JL2 in Lake St-Joseph, dated at 1785 AD, 1704 AD 491 and $\sim 1366 \mathrm{AD}$, respectively. However, even if a seismic trigger is possible for the RDLs 492 SL1, SL2 and JL1, other local or inter-basin trigger mechanisms such as flood or 493 anthropogenic disturbances are also possible. The RDLs do not show the synchronously-aged 494 multiple deposits key signature of a seismic trigger and our investigations were aimed on 495 only one core from each lake. RDLs might not be recorded in the entire lake basin area, 496 suggesting that single coring investigations do not necessarily provide information on the 497 disturbance rate of a lacustrine basin and paleoseismological investigations should focus on 498 multiple cores sampled from different sites. Coring investigations aiming to reconstruct the 499 history of seismically induced RDLs should also take place away from the sedimentary input 500 of the river mouth.

\section{CONCLUSIONS}

502 High resolution swath bathymetric imagery, sub-bottom profiler and sediment core data 503 collected in three lakes (Maskinongé, Aux-Sables and St-Joseph) located near two active 
504 seismic zones (WQSZ and CKSZ) in south-central Québec reveal that the lacustrine basins 505 were highly disturbed by three distinct phases of seismically-induced mass-movements since 506 deglaciation, without any event between late-deglacial and late postglacial times. These 507 mass-movements are interpreted to have a seismic triggering due to 1) the widespread 508 distribution of MMDs, covering $\geq 34 \%$ of each lacustrine basin area; 2) the presence of 509 disturbed slopes with headwall scarps located far from a sedimentary input; 3) the occurrence 510 of many MMDs along the same stratigraphic level, suggesting synchronous events; and 4) 511 the presence of liquefaction structures observed on sub-bottom profiles.

512 MMDs were observed at different stratigraphic levels on sub-bottom profiles of the 513 investigated lakes, allowing the identification of three different phases of seismic events.

514 Taken together, the stratigraphic position of the MMDs and the depositional rates suggest 515 that: Phase 1 occurred during the deglacial Champlain Sea episode (11.1 to 10.5 cal. Ka BP) 516 and produced many mass-movements, when rates of glacio-isostatic rebound were high; 517 Phase 2 around $1180 \mathrm{AD}$, which is in agreement with a large-scale terrestrial landslide 518 observed in Quyon Valley (western Québec) dated at 1020 cal. yr BP (Brooks, 2013a); and 519 Phase 3 corresponding to the well documented CKSZ 1663 AD historical earthquake. 520 However, aseismic triggers are still considered for the first phase of mass-movement deposits 521 because deglacial environments were characterized by high sedimentation rates and water 522 level variation. The ${ }^{210} \mathrm{~Pb}$ analysis revealing a depositional rate of $0.07 \mathrm{~cm} \mathrm{yr}^{-1}$ in Lake St523 Joseph allow us to revise the Normandeau et al (2013) date for a large-scale MMD to the M $524 \geq 7$ historical 1663 AD event.

525 Even though the dating represents a minimal age due to errors induced by the sediment 
526 compaction and time-traveling-depth variations in the sediments, taken together, our dataset

527 leads us to conclude that a high magnitude seismic event occurred a few hundred years before

528 the CKSZ 1663 AD historical earthquake. We observed that a large-scale MMDs event (ME2:

$5294.09 \mathrm{~km}^{2}, \leq 7 \mathrm{~m}$ thick) recorded in Lake Maskinongé was seismically-induced by the WQSZ

$530 \mathrm{M} \geq 6.3$ earthquake previously reported by Brooks (2013a) and dated at $\sim 1020 \mathrm{yr}$ BP.

531 The largest MMDs in the three lakes do not correspond to the same phases (Phase 2 in Lake

532 Maskinongé vs Phase 3 in Lake Aux-Sables and St-Joseph) suggesting that the seismological 533 events epicenters occured at different location (WQSZ vs CKSZ). Although Phase $2(\sim 1020$

534 yr BP) MMDs are more extensive in Lake Maskinongé than those of Phase 3 (1663 AD, M>7)

535 MMDs, the event of Phase 2 was not necessarily of a higher magnitude because the 536 occurrence of a mass-movement a few hundred years prior to the 1663 AD historical 537 earthquake must have reduced the sediment availability. Investigations aiming to reconstruct 538 paleoearthquakes must contextualized MMDs in a regional stratigraphic framework and 539 consider the recurrence of slope failures. More morphostratigraphic and sediment core data 540 are needed in eastern Canada to define the extent, exact timing and geomorphological impact 541 of the events of phases $2 \& 3$.

542 This study has demonstrated that hydroacoustic investigations coupled with the analysis of 543 sediment cores in lakes located farther away from an active seismic zone provide a reliable 544 record of strong earthquakes in a context of frequent lower magnitudes earthquakes and low 545 sedimentation rates. Different levels of MMDs can be identified in the lakes basin infill, but 546 these deposits must all be separated by normal sedimentation to deduce their thickness and 547 depth. 
548 The coring data show that RDLs are not necessarily related to seismically-induced

549 sublacustrine mass-movements, but can be generated by different events occurring in a lake

550 basin and watershed. Moreover, RDL analysis does not provide information on the

551 disturbance rate of a lacustrine basin since they might not always be observed in the cores.

552 Therefore, sediment core data are considered complementary to swath bathymetric imagery

553 and sub-bottom profiler data and contextualizing them in a morphostratigraphic framework

554 enhances the detail of paleoseismological reconstructions. Further investigations using a

555 lower frequency subbottom profiler (e.g., boomer) showing the entire Quaternary

556 stratigraphic sequence and multiple long sediment cores should be undertaken in these lakes

557 as well as others of eastern Canada in order to extend the sedimentary archives of mass-

558 movements.

\section{ACKNOWLEDGMENTS}

560 The research was funded by a Discovery grant from the Natural Science and Engineering 561 Research Council of Canada (NSERC) to P.L. Survey instruments were acquired from 562 Canadian Foundation for Innovation (CFI) and the Ministère de l'Éducation du Québec. We 563 thank the Centre touristique Duchesnay for their accommodations and the lake access. We 564 thank François-Xavier L'Heureux-Houde for his assistance during fieldwork and Gabriel 565 Joyal for his technical and scientific support. Pierre Francus (INRS ETE) and Dermot 566 Antoniades (U.Laval) provided helpful comments on a previous version of the manuscript.

567 We also thank G. Brooks (Geological Survey of Canada) and an anonymous reviewer for 568 providing valuable comments that improved the quality of the manuscript. 


\section{REFERENCES CITED}

570 Adams, J., Basham P. (1989) The seismicity and seismotectonics of Canada east of the

571 Cordillera. Geoscience Canada, 16 (1): 3-16

572 ArchivesCanada: http://archivescanada.accesstomemory.ca/mastigouche-riviere-dautray573 quebec

574 Arnaud, F., Lignier, V., Revel, M., Desmet, M., Beck, C., Pourchet, M., Charlet, F., 575 Trentesaux, A., Tribovillard, N. (2002) Flood and earthquake disturbance of $210 \mathrm{~Pb}$ 576 geochronology (Lake Anterne, NW Alps). Terra Nova, 14: 225-232

577 Arnaud, F., Revel, M., Chapron, E., Desmet, M., Tribovillard, N. (2007) 7200 years of 578 Rhône River flooding activity in Lake Le Bourget, France: a high-resolution sediment 579 record of NW Alps hydrology. The Holocene: 420-428

580 Aylsworth, J.M., Lawrence, D.E., Guertin, J. (2000) Did two massive earthquakes in the 581 Holocene induce widespread landsliding and near-surface deformation in part of the 582 Ottawa Valley, Canada? Geology 28: 903-906

583 Beck, C. (2009) Late Quaternary lacustrine paleo-seismic archives in north-western Alps: 584 Examples of earthquake-origin assessment of sedimentary disturbances. Earth-Science 585 Reviews, 96: 327-344

586 Beck, C., Manalt, F., Chapron, E., Van Rensbergen, P., De Batist, M. (1996) Enhanced 587 seismicity in the early post-glacial period: evidence from the post-würm sediments of Lake 588 Annecy, Northwestern Alps. Journal of Geodynamics, 22 (1/2): 155-171 
589 Bertrand, S., Charlet, F., Chapron, E., Fagel, N., De Batist, M. (2008) Reconstruction of

590 the Holocene seismotectonic activity of the Southern Andes from seismites recorded in

591 Lago Icalma, Chile. Palaeogeography, Palaeoclimatology, Palaeoecology, 259: 301-322

592 Brooks, G.R. (2013a) A massive sensitive clay landslide, Quyon Valley, southwestern

593 Quebec, Canada, and evidence for a paleoearthquake triggering mechanism. Quaternary

594 Research, 80: 425-434.

595 Brooks, G.R. (2013b) Prehistoric sensitive clay landslides and paleoseismicity in the

596 Ottawa Valley, Canada. In Landslides in sensitive clays: from geosciences to risk

597 management, L’Heureux, J.-S., Locat, A., Leroueil, S. Demers, D. and Locat, J. (eds.), 598 Advances in Natural and Technological Hazards Research 36, Springer Netherlands, 599 Dordrecht: 119-131.

600 Brooks, G.R. (2015) An integrated stratigraphic approach to investigating evidence of 601 paleoearthquakes in lake deposits of eastern Canada. Geoscience Canada, 42: 247-261.

602 Brooks, G. R. (2016) Evidence of late glacial paleoseismicity from submarine landslide 603 deposits within Lac Dasserat, northwestern Quebec, Canada. Quaternary Research, 86 (2): 604 184-199

605 Cauchon-Voyer, G., Locat, J., St-Onge, G. (2008) Late-Quaternary morpho-sedimentology 606 and submarine mass mouvements of the Betsiamites area, Lower St. Lawrence esturay, 607 Quebec, Canada. Marine Geology, 251: 233-252

608 Chappaz, A., Gobeil, C., Tessier, A. (2008) Sequestration mechanisms and anthropogenic 
609 inputs of rhenium in sediments from Eastern Canada lakes. Geochimia et Cosmochimica

610 Acta, 72: 6027-6036

611 Chapron, E., Van Rensbergen, P., Beck, C., De Batist, M., Paillet, A. (1996) Lacustrine

612 sedimentary records of brutal events in Lake Le Bourget (Northwestern Alps-Southern

613 Jura). Quaternaire, 7 (2-3): 155-168

614 Chapron, E., Beck, C., Pourchet, M., Deconinck, J.F. (1999) 1822 earthquake-triggered

615 homogenite in Lake Le Bourget (NW Alps). Terra Nova, 11: 86-92

616 Chapron, E., Faïn, X., Magand, O., Charlet, L., Debret, M., Mélières, M.A. (2007)

617 Reconstructing recent environmental changes from proglacial lake sediments in the

618 Western Alps (Lake Blanc Huez, 2543 m a.s.1., Grandes Rousses Massif, France).

619 Palaeogeography, Palaeoclimatology, Palaeoecology, 252: 586-600

620 De Blasio, F.V., Engvik, L., Harbitz, C.B., Elverhøi, A. (2004) Hydroplaning and

621 submarine debris flows. Journal of Geophysical Research, 109: 1-15

622 Doig, R. (1986) A method for determining the frequency of large magnitude earthquakes

623 using lake sediments. Canadian Journal of Earth Sciences, 23: 930-937

624 Doig, R. (1991) Effects of strong seismic shaking in lake sediments, and earthquake 625 recurrence interval, Temiscaming, Quebec. Canadian Journal of Earth Sciences, 28: 1349$626 \quad 1352$

627 Doig, R. (1998) 3000-Year paleoseismological record from the region of the 1988 628 Saguenay, Quebec, earthquake. Bulletin of the Seismological Society of America, 88 (5): 
630 Doughty, M., Eyles, N., Daurio, L. (2010a). Ongoing neotectonic activity in the

631 Timiskaming- Kipawa area of Ontario and Québec. Geoscience Canada 37(3): 1-8.

632 Doughty, M., Eyles, N. and Daurio, L. (2010b) Earthquake-triggered slumps (1935

633 Timiskaming M6.2) in Lake Kipawa, Western Quebec Seismic Zone,

634 Canada. Sedimentary Geology 228: 113-118.

635 Doughty, M., Eyles, N., Eyles, C., Talling, P. (2013). High-resolution seismic reflection

636 profiling of neotectonic faults in Lake Timiskaming, Timiskaming Graben, Ontario637 Quebec, Canada. Sedimentology 60(4): 983-1006.

638 Doughty, M., Eyles, N., Eyles, C.H., Wallace, K., Boyce, J.I. (2014) Lake sediments as 639 natural seismographs: Earthquake-related deformations (seismites) in central Canadian 640 lakes. Sedimentary Geology, 313: 45-67

641 Duboc, Q., St-Onge, G., \& Lajeunesse, P. (2017). Sediment records of the influence of 642 river damming on the dynamics of the Nelson and Churchill Rivers, western Hudson Bay, 643 Canada, during the last centuries. The Holocene, 27(5): 712-725.

644 Duchesne, M.J., Pinet, N., Bédard, K., St-Onge, G., Lajeunesse, P., Calvin Campbell, D., 645 Bolduc, A. (2010) Role of the bedrock topography in the Quaternary filling of a giant 646 estuarine basin : The lower St. Lawrence estuary, Eastern Canada. Basin Research, 22: $647 \quad 933-951$

648 Fanetti, D., Anselmetti, F.S., Chapron, E., Sturm, M., Vezzoli, L. (2008) Megaturbidite 
649 deposits in the Holocene basin fill of Lake Coo (Southern Alps, Italy). Palaeogeography,

650 Palaeoclimatology, Palaeoecology, 259: 323-340

651 Gagné, H., Lajeunesse, P., St-Onge, G., Bolduc, A. (2009) Recent transfert of coastal 652 sediments to the Laurentian Channel, Lower St. Lawrence Estuary (Eastern Canada), 653 through submarine canyon and fan system. Geo-Marine Letters, 29 (3): 191-200

654 Henkel, D.J. (1970) The role of waves in causing submarine landslides. Geotechnique, 20: $655 \quad 75-80$

656 Hilbe, M, Anselmetti, F.S. (2014) Signature of slope failures and river-delta collapses in a 657 perialpine lake (Lake Lucerne, Switzerland). Sedimentology, 61: 1883-1907

658 Hilbe, M., Anselmetti, F.S., Eilertsen, R.S., Hansen, L., Wildi, W. (2011) Subaqueous 659 morphology of Lake Lucerne (Central Switzerland): implications for mass movements and 660 glacial history. Swiss Journal of Geosciences, 104: 425-443

661 Lajeunesse, P., \& Allard, M. (2002). Sedimentology of an ice-contact glaciomarine fan 662 complex, Nastapoka Hills, eastern Hudson Bay, northern Québec. Sedimentary Geology, $663 \quad 152(3-4): 201-220$.

664 Lajeunesse, P., St-Onge, G. (2008) Mouvements de masse subaquatiques postglaciaires au 665 lac Jacques-Cartier, Réserve faunique des Laurentides. $4^{\mathrm{e}}$ conférence canadienne sur les 666 géorisques : des causes à la gestion. Presse de 1’Université Laval, Québec: 313-321

667 Lajeunesse, P., Sinkunas, B., Morissette, A., Normandeau, A., Joyal, G., St-Onge, G., 668 Locat, J. (2017) Large-scale seismically-induced mass-movements in a former glacial lake 
669 basin: Lake Témiscouata, northeastern Appalachians (eastern Canada). Marine Geology,

670 doi: 10.1016/j.margeo.2016.04.007

671 Lamontagne, M. (1987) Seismic activity and structural features in the Charlevoix region, 672 Quebec. Canadian Journal of Earth Sciences, 24: 2118-2129

673 Lauterbach, S., Chapron, E., Brauer, A., Hüls, M., Gilli, A., Arnaud, F., Piccin, A., Nomade, 674 J., Desmet, M., von Grafenstein, U. (2012) A sedimentary record of Holocene surface 675 runoff events and earthquake activity from Lake Iseo (Southern Alps, Italy). The Holocene, $67622(7): 749-760$

677 Ledoux, G., Lajeunesse, P., Chapron, E., St-Onge, G. (2010) Multibeam Bathymetry 678 Investigations of Mass Movements in Lake Le Bourget (NW Alps, France) Using a 679 Portable Platform. Submarine Mass Movements and Their Consequences, Advances in 680 Natural and Technological Hazards Research, 28: 423-434

681 Locat, J., Lee, H.J. (2002) Submarine landslides: advances and challenges. Canadian 682 Geotechnical Journal, 39: 193-212

683 Locat, J. (2011) La localisation et la magnitude du séisme du 5 février 1663 (Charlevoix) 684 revues à l'aide des mouvements de terrain. Canadian Geotechnical Journal, 48: 1266-1286

685 Locat, J., Turmel, D., Habersetzer, M., Trottier, A.P., Lajeunesse, P., St-Onge, G. (2016) 686 Earthquake Induced Landslides in Lake Éternité, Québec, Canada. Submarine Mass 687 Movements and Their Consequences, Advances in Natural and Technological Hazards 688 Research, 41:361-370 
689 Moernaut, J., De Batist, M. (2011) Frontal emplacement and mobility of sublacustrine

690 landslides: Results from morphometric and seismostratigraphic analysis. Marine Geology,

$691 \quad 285: 29-45$

692 Monecke, K., Anselmetti, F.S., Becker, A., Sturm, M., Giardini, D. (2004) The record of

693 historic earthquakes in lake sediments of Central Switzerland. Tectonophysics, 394: 21-40

694 Natural Resources Canada (2018) Earthquakes Canada.

695 http://www.earthquakescanada.nrcan.gc.ca

696 Nomade, J., Chapron, E., Desmet, M., Reyss, J.L., Arnaud, F., Lignier, V. (2005)

697 Reconstructing historical seismicity from lake sediments (Lake Laffrey, Western Alps, 698 France). Terra Nova, 17: 350-357

699 Normandeau, A., Lajeunesse, P., Philibert, G. (2013) Late-Quaternary morphostratigraphy 700 of Lake St-Joseph: Evolution from a semi-enclosed glaciomarine basin to a postglacial lake.

701 Sedimentary Geology, 295: 38-52

702 Normandeau, A., Lajeunesse, P., Trottier, A-P., G. Poiré, A., Pienitz, R. (2017)

703 Sedimentation in isolated glaciomarine embayments during glacio-isostatically induced

704 relative sea level fall (northern Champlain Sea basin). Canadian Journal of Earth Sciences, 705 54(10): 1049-1062

706 Occhietti, S. (2007) The Saint-Narcisse morainic complex and early Younger Dryas events 707 on the southeastern margin of the Laurentide Ice Sheet. Géographie physique et 708 Quaternaire, 61: 89-117. 
709 Occhietti, S., Parent, M., Lajeunesse, P., Robert, F., Govare, E. (2011) Late Pleistocene -

710 Early Holocene decay of the Laurentide Ice Sheet in Québec-Labrador. In: Ehlers, J.,

711 Gibbard, P.L. (Eds.), Quaternary Glaciations - Extent and Chronology: Part IV: A closer

712 look. Developments in Quaternary Science 15. Elsevier Science: 601-630.

713 Occhietti, S., Richard, P. (2003). Effet réservoir sur les âges 14C de la Mer de Champlain

714 à la transition Pléistocène-Holocène: révision de la chronologie de la déglaciation au

715 Québec méridional. Géographie physique et Quaternaire, 57(2-3): 115-138.

716 Ouellet, M. (1997) Lake Sediments and Holocene seismic hazard assessment within the St.

717 Lawrence Valley, Québec. Geological Society of America Bulletin, 109 (6): 631-642

718 Parent, M., Occhietti, S. (1988) Late Wisconsinan Deglaciation and Champlain Sea

719 Invasion in the St. Lawrence Valley, Québec. Géographie physique et Quaternaire, 42 (3):

$720 \quad 215-246$

721 Père Pierre Gouin (2001) «Historical» earthquakes felt in Québec. Guérin éditeur ltée,

722 Montreal

723 Praet, N., Moernaut, J., Van Daele, M., Boes, E., Haeussler, P.J., Strupler, M., Schmidt, S.,

724 Loso, M.G., De Batist, M. (2016) Paleoseismic potential of sublacustrine landslide records

725 in a high-seismicity setting (south-central Alaska). Marine Geology, doi:

$726 \quad$ 10.016/j.margeo.2016.05.004

727 Schnellmann, M., Anselmetti, F.S., Giardini, D., McKenzie, J.A. (2006) 15.000 Years of

728 mass-movement history in Lake Lucerne: Implications for seismic and tsunami hazards. 
729 Eclogae Geologicae Helvetiae, 99: 409-428

730 Schnellmann, M., Anselmetti, F.S., Giardini, D., McKenzie, J.A., Ward, S.N. (2002)

731 Prehistoric earthquake history revealed by lacustrine slump deposits. Geological Society 732 of America Bulletin, 30 (12): 1131-1134

733 Shilts, W.W. (1984) Sonar evidence for postglacial tectonic instability of the Canadian

734 Shield and Appalachians. Current Research, Part A, Geological Survey of Canada: 567$735 \quad 579$

736 Shilts, W.W., Rappol, M., Blais, A. (1992) Evidence of late and postglacial seismic activity 737 in the Temiscouata-Madawaska valley, Quebec-New Brunswick, Canada. Canadian 738 Journal of Earth Sciences, 29: 1043-1069

739 Shilts, W.W., Clague, J.J. (1992) Documentation of earthquake-induced disturbance of

740 lake sediments using subbottom acoustic profiling. Canadian Journal of Earth Sciences, $741 \quad 29: 1018-1042$

742 Sims, J.D. (1975) Determining earthquake recurrence intervals from deformational 743 structures in young lacustrine sediments. Tectonophysics, 29: 141-152

744 Smith, S.B., Karlin, R.E., Kent, G.M., Seitz, G.G., Driscoll, N.W. (2013) Holocene 745 subaqueous paleoseismology of Lake Tahoe. Geological Society of America Bulletin, 125 $746 \quad(5 / 6): 691-708$ 
747 St-Onge, G., Mulder, T., Piper, D. J., Hillaire-Marcel, C., \& Stoner, J. S. (2004).

748 Earthquake and flood-induced turbidites in the Saguenay Fjord (Québec): a Holocene

749 paleoseismicity record. Quaternary Science Reviews, 23(3): 283-294.

750 St-Onge, G., Chapron, E., Mulsow, S., Salas, M., Viel, M., Debret, M., ... \& Costa, P. J.

751 (2012). Comparison of earthquake-triggered turbidites from the Saguenay (Eastern

752 Canada) and Reloncavi (Chilean margin) Fjords: Implications for paleoseismicity and 753 sedimentology. Sedimentary Geology, 243: 89-107.

754 Strasser, M., Anselmetti, F.S., Fäh, D., Giardini, D., Schnellmann, M. (2006) Magnitudes

755 and source areas of large prehistoric northern Alpine earthquakes revealed by slope failures

756 in lake. Geological Society of America Bulletin, 34 (12): 1005-1008

757 Strasser, M., Hilbe, M., Anselmetti, F.S. (2011) Mapping basin-wide subaquatic slope 758 failure susceptibility as a tool to assess regional seismic and tsunami hazards. Marine

759 Geophysical Research, 32: 331-347

760 Tremblay, A., Roden-Tice, M. K., Brandt, J. A., Megan, T. W. (2013). Mesozoic fault

761 reactivation along the St. Lawrence rift system, eastern Canada: Thermochronologic

762 evidence from apatite fission-track dating. Geological Society of America Bulletin 125(5-

763 6): 794-810.

764 Tuttle, M., Atkinson, G.M. (2010) Localization of large earthquakes in the Charlevoix 765 seismic zone, Quebec, Canada, during the past 10000 years. Seismological Research

766 Letters, 81 (1): 140-147 
767 Wilhelm, B., Nomade, J., Crouzet, C., Litty, C., Sabatier, P., Belle, S., Anselmetti, F. S.

768 (2016). Quantified sensitivity of small lake sediments to record historic earthquakes:

769 Implications for paleoseismology. Journal of Geophysical Research: Earth Surface, 121(1):

$770 \quad 2-16$.




\section{Table of figures}

772 Figure 1 - A) Seismic hazard potential in Canada (modified from NRCan); B) Location 773 map of the investigated lakes north of the St. Lawrence River within the deglacial

774 Champlain Sea limit and between two active seismic zones: the Western Québec seismic

775 zone (WQSZ) and the Charlevoix-Kamouraska seismic zone (CKSZ).

776 Figure 2 - Morphologies and facies associated with sublacustrine mass-movements as observed on the hydroacoustic data of the investigated lakes.

Figure 3 - General stratigraphic framework observed on the acoustic sub-bottom profiles of the investigated lakes summarizing the units (U1 to U7) previously identified by Normandeau et al. (2013, 2017): Ua till or bedrock; Ub glaciomarine Champlain Sea deposits; and Uc paraglacial and postglacial units.

Figure 4 - A) High-resolution swath bathymetric imagery of Lake Maskinongé with location of acoustic sub-bottom profiles and coring site; B) Geomorphological map of the lake showing disturbed basin morphologies: a wide MMD, headwall scarps and undisturbed mounds. Linear to sinuous features are also visible at the Mastigouche River mouth.

Figure 5 - Acoustic sub-bottom profiles $(12 \mathrm{kHz})$ of Lake Maskinongé showing the glaciomarine $(\mathrm{Ub})$ and the paraglacial and postglacial (Uc) sediments. MMDs facies are observed along three different stratigraphic levels: Event ME1 buried in Ub and Events ME2 \& ME3 in Uc. Note that the uppermost MMD facies (ME3) is only visible on profile $\mathrm{C}$ at a depth of $0.5-1.0 \mathrm{~m}$.

Figure $6-3 \mathrm{D}$ view of the high-resolution swath bathymetric imagery of Lake Maskinongé coupled with an acoustic profile. The hummocky topography observed on the basin floor correlate with the extent of the deposit of event ME2, suggesting that the disturbed morphology of Lake Maskinongé was caused by the second phase of mass-movement.

Figure 7 - Photography, CT-Scan image, CT-number, magnetic susceptibility and location on acoustic sub-bottom profiles of the cores sampled in Lake Maskinongé (MAS15-1aP), Aux-Sables (LAS15-1P) and St-Joseph (LSJ15-1bP). Layers of high CT-number and magnetic susceptibility values are visible on the upper section of the cores and their date of deposition were inferred from each lake respective sedimentation rate.

803

804 Figure 9 - A) High-resolution swath bathymetric imagery of Lake Aux-Sables with 805 location of acoustic sub-bottom profiles and coring site; B) Geomorphological map of the 806 lake showing disturbed basin morphologies: wide MMDs and numerous headwall scarps. 
807 Figure 10 -3D view of the high-resolution swath bathymetric imagery of Lake Aux-Sables

808 showing the direction of flow of mass-movements and the extent of their deposits on the

809 basin floor.

810 Figure 11 - Acoustic sub-bottom profiles $(3.5 \mathrm{kHz})$ of Lake Aux-Sables showing the ice811 contact (Ua), the glaciomarine (Ub) and the paraglacial and postglacial (Uc) sediments.

812 Recent MMDs facies are observed in Uc on both profiles.

813 Figure 12 - A) High-resolution swath bathymetric imagery of Lake St-Joseph with location 814 of acoustic sub-bottom profiles and coring site; B) Geomorphological map of the lake 815 showing disturbed basin morphologies: wide MMD, headwall scarps, an undisturbed 816 mound and compression ridges.

817 Figure $13-3 \mathrm{D}$ view of the high-resolution swath bathymetric imagery of Lake St-Joseph 818 showing the direction of flow of mass-movement and the extent of its deposit. Compression 819 ridges are visible in zone of frontal thrusting.

820 Figure 14 - Acoustic sub-bottom profiles $(12 \mathrm{kHz})$ of Lake St-Joseph showing the ice821 contact $(\mathrm{Ua})$, the glaciomarine $(\mathrm{Ub})$ and the paraglacial and postglacial (Uc) sediments. 822 MMDs facies are observed along three different stratigraphic levels: Events JE1 and JE2 823 buried in Ub and Event JE3 in Uc. 


\section{Table 1}

Physical characteristics of the investigated lakes.

\begin{tabular}{|c|c|c|c|c|c|c|}
\hline Lake & Coordinates & $\begin{array}{c}\text { Elevation } \\
\text { (m) asl }\end{array}$ & $\begin{array}{c}\text { Distance } \\
\text { from } \\
\text { WQSZ } \\
*(\mathrm{~km})\end{array}$ & $\begin{array}{c}\text { Distance } \\
\text { from } \\
\text { CKSZ } \\
*(\mathrm{~km})\end{array}$ & $\begin{array}{l}\text { Maximum } \\
\text { depth (m) }\end{array}$ & $\begin{array}{l}\text { Area } \\
\left(\mathrm{km}^{2}\right)\end{array}$ \\
\hline Maskinongé & $\begin{array}{l}46^{\circ} 19.78 \mathrm{~N} \\
73^{\circ} 23.92 \mathrm{~W}\end{array}$ & 140 & 140 & 285 & 25 & 10.2 \\
\hline Aux-Sables & $\begin{array}{l}46^{\circ} 52.93 \mathrm{~N} \\
72^{\circ} 21.95 \mathrm{~W}\end{array}$ & 150 & 235 & 185 & 41 & 5.2 \\
\hline St-Joseph & $\begin{array}{l}46^{\circ} 55.00 \mathrm{~N} \\
71^{\circ} 39.00 \mathrm{~W}\end{array}$ & 160 & 290 & 135 & 37 & 11.3 \\
\hline
\end{tabular}


Table 2

Description and location of cores collected in the investigated lakes.

\begin{tabular}{ccccc}
\hline Core number & Lake & Coordinates & Depth $(\mathbf{m})$ & Length $(\mathbf{c m})$ \\
\hline \multirow{2}{*}{ MAS15-1aP } & Maskinongé & $46^{\circ} 18.73 \mathrm{~N}$ & 18.5 & 105 \\
& & $73^{\circ} 23.43 \mathrm{~W}$ & & 131 \\
LAS15-1P & Aux-Sables & $46^{\circ} 53.12 \mathrm{~N}$ & 39 & 123 \\
& & $72^{\circ} 22.00 \mathrm{~W}$ & & \\
LSJ15-1bP & St-Joseph & $46^{\circ} 54.82 \mathrm{~N}$ & 37 & \\
\hline
\end{tabular}


Table 3

Depth, thickness and date of the layers observed in each core.

\begin{tabular}{lccccc}
\hline Core number & Layer & Depth $(\mathbf{c m})$ & Thickness $(\mathbf{c m})$ & Depositional rate $\left(\mathbf{c m ~ y r}^{-1}\right)$ & Calendar age (AD) \\
\hline MAS15-1aP & ML1 & 8.5 & 3.0 & 0.18 & 1969 \\
\hline LAS15-1P & SL1 & 5.5 & 4.5 & 0.08 & 1947 \\
LAS15-1P & SL2 & 23 & 3.5 & 0.08 & 1785 \\
LAS15-1P & SL3 & 35 & 6.0 & 0.08 & 1704 \\
\hline LSJ15-1bP & JL1 & 19 & 3.5 & 0.07 & 1745 \\
LSJ15-1bP & JL2 & 49 & 1.0 & 0.07 & 1366 \\
\hline
\end{tabular}




\section{Table 4}

Summarize of the three phases of mass-movements with their respective deposits, date and seismic trigger event.

\begin{tabular}{|c|c|c|c|c|c|c|}
\hline Phase & MMDs event & Depth (m) & $\begin{array}{c}\text { Maximal } \\
\text { thickness (m) }\end{array}$ & $\begin{array}{c}\text { Calculated calendar } \\
\text { age* (AD) }^{*}\end{array}$ & Seismic event & $\begin{array}{c}\text { Seismic } \\
\text { zone }\end{array}$ \\
\hline \multirow{3}{*}{1} & ME1 & $5.5-6.0$ & - & \multirow{3}{*}{$\begin{array}{c}\text { Deglacial Champlain Sea } \\
\text { transgression }\end{array}$} & \multirow{3}{*}{11.1 to $10.5 \mathrm{Ka}$ yr BP } & \multirow{3}{*}{ - } \\
\hline & JE1 & $>5.5$ & 4 & & & \\
\hline & JE2 & 5.5 & 3 & & & \\
\hline \multirow[t]{2}{*}{2} & ME2 & 1.5 & 7 & 1180 & $\sim 1020 \mathrm{yr} \mathrm{BP}$ & WQSZ \\
\hline & ME3 & $0.5-1.0$ & 1.5 & 1739 & & \\
\hline \multirow[t]{2}{*}{3} & SE1 & - & 5 & - & $1663 \mathrm{AD}$ & CKSZ \\
\hline & JE3 & $0.5-1.0$ & 10 & 1685 & & \\
\hline
\end{tabular}

*Note that the calculated age represent a minimal age. 


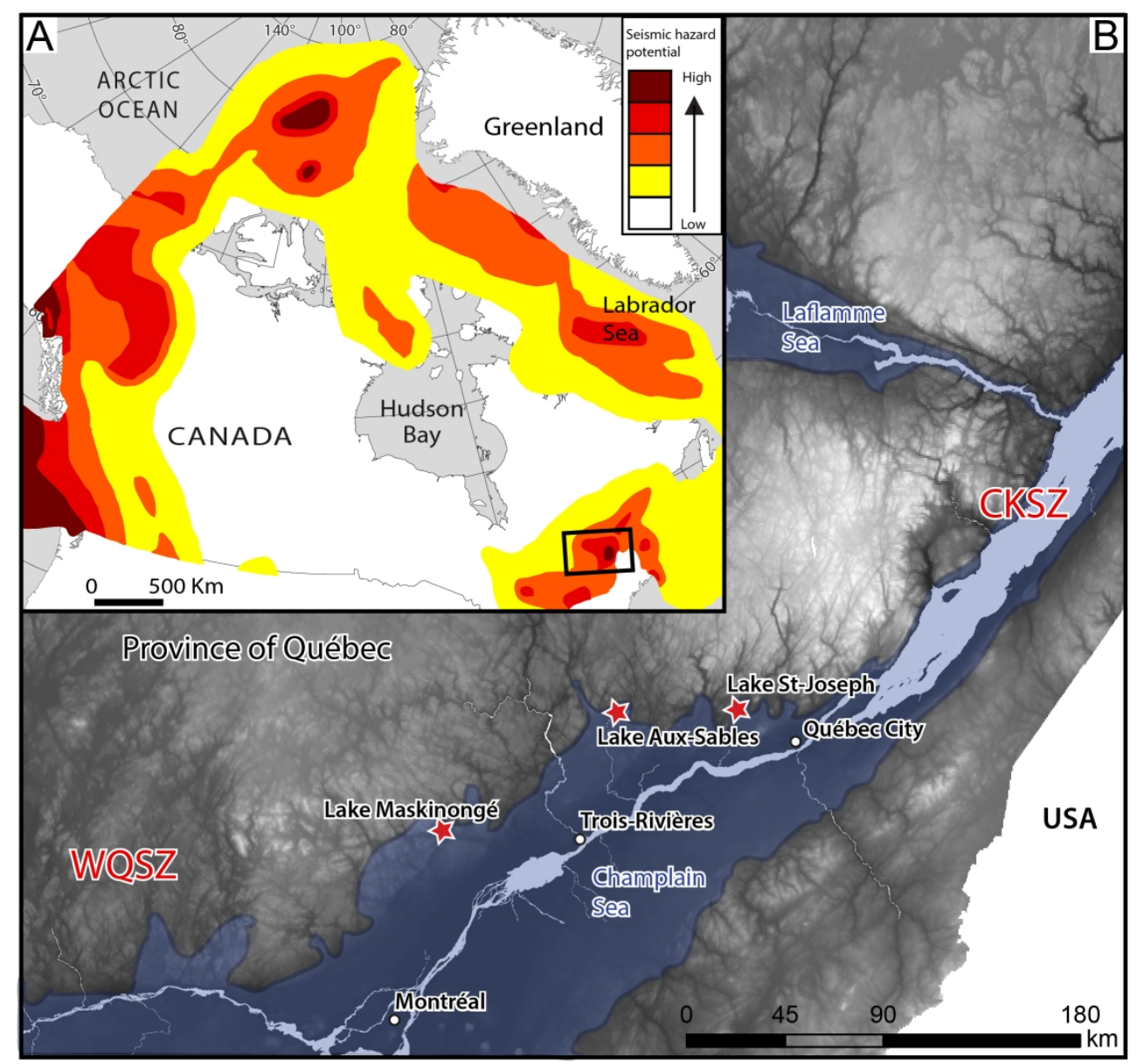

Figure 1 - A) Seismic hazard potential in Canada (modified from NRCan); B) Location map of the investigated lakes north of the St. Lawrence River within the deglacial Champlain Sea limit and between two active seismic zones: the Western Québec seismic zone (WQSZ) and the Charlevoix-Kamouraska seismic zone (CKSZ).

$193 \times 183 \mathrm{~mm}(300 \times 300 \mathrm{DPI})$ 


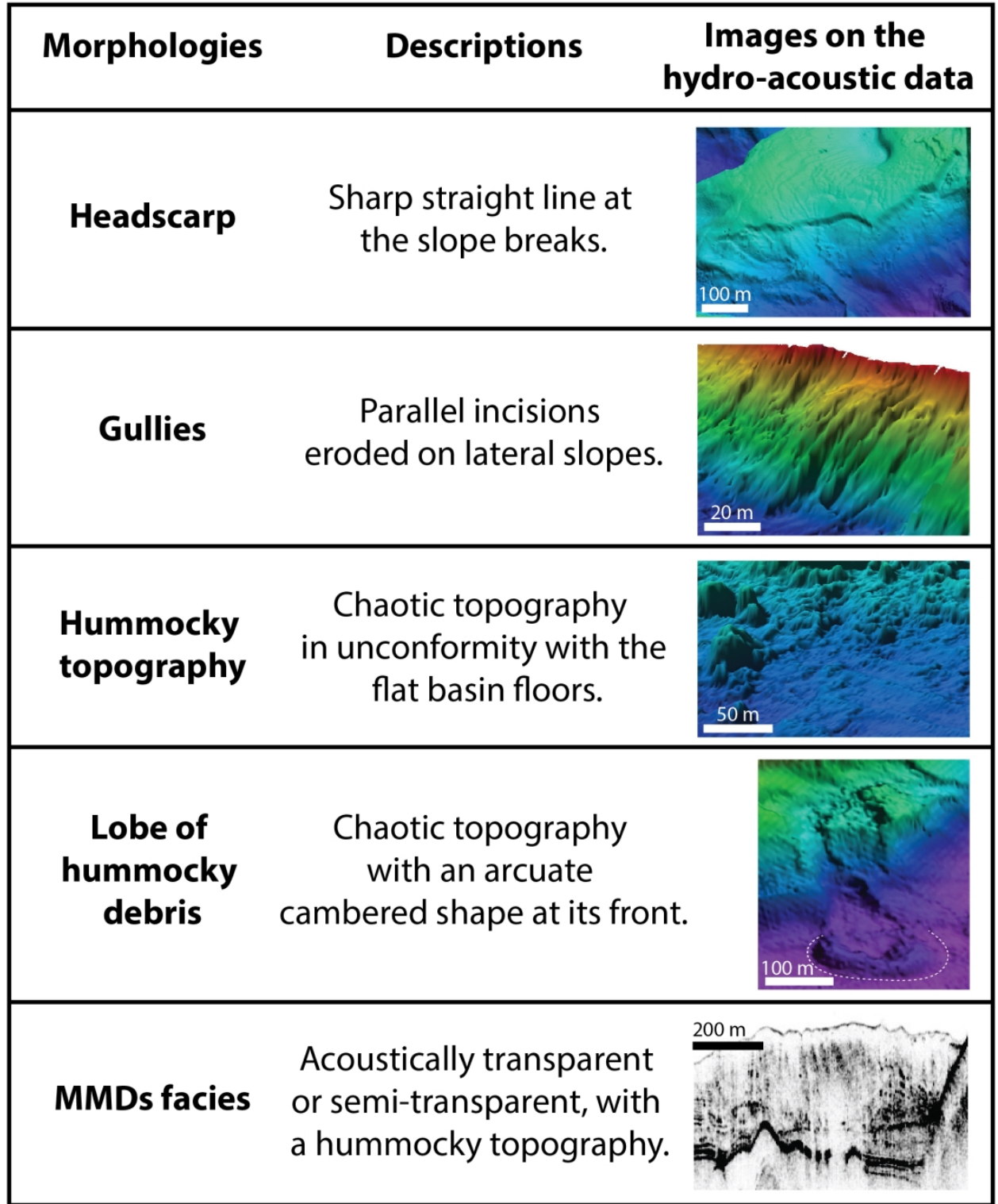

Figure 2 - Morphologies and facies associated with sublacustrine mass-movements as observed on the hydro-acoustic data of the investigated lakes. 


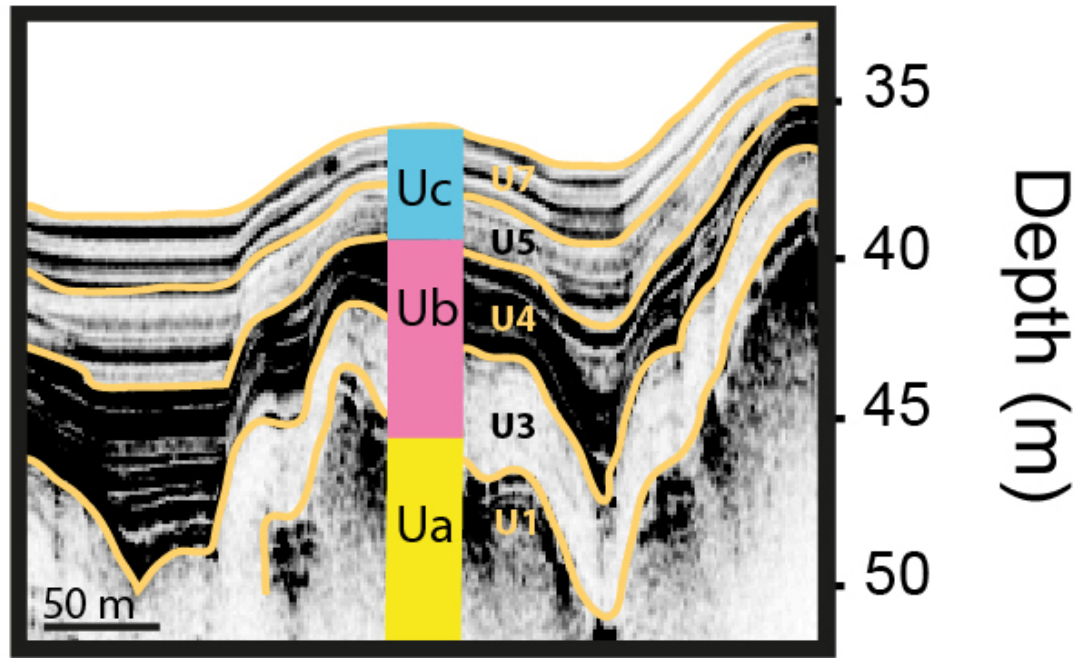

Figure 3 - General stratigraphic framework observed on the acoustic sub-bottom profiles of the investigated lakes summarizing the units (U1 to U7) previously identified by Normandeau et al. (2013, 2017): Ua till or bedrock; Ub glaciomarine Champlain Sea deposits; and Uc paraglacial and postglacial units.

$60 \times 40 \mathrm{~mm}(300 \times 300 \mathrm{DPI})$ 


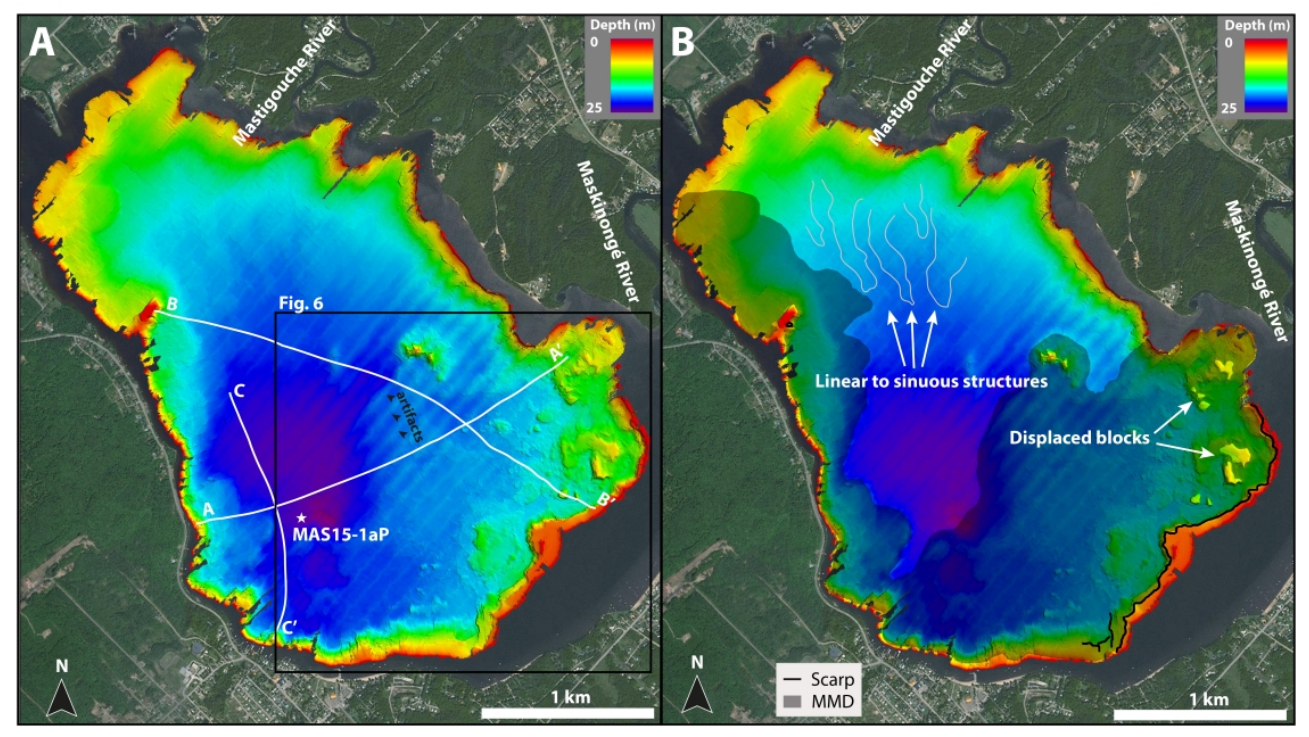

Figure $4-$ A) High-resolution swath bathymetric imagery of Lake Maskinongé with location of acoustic subbottom profiles and coring site; B) Geomorphological map of the lake showing disturbed basin morphologies: a wide MMD, headwall scarps and undisturbed mounds. Linear to sinuous features are also visible at the Mastigouche River mouth.

$437 \times 246 \mathrm{~mm}(300 \times 300 \mathrm{DPI})$ 

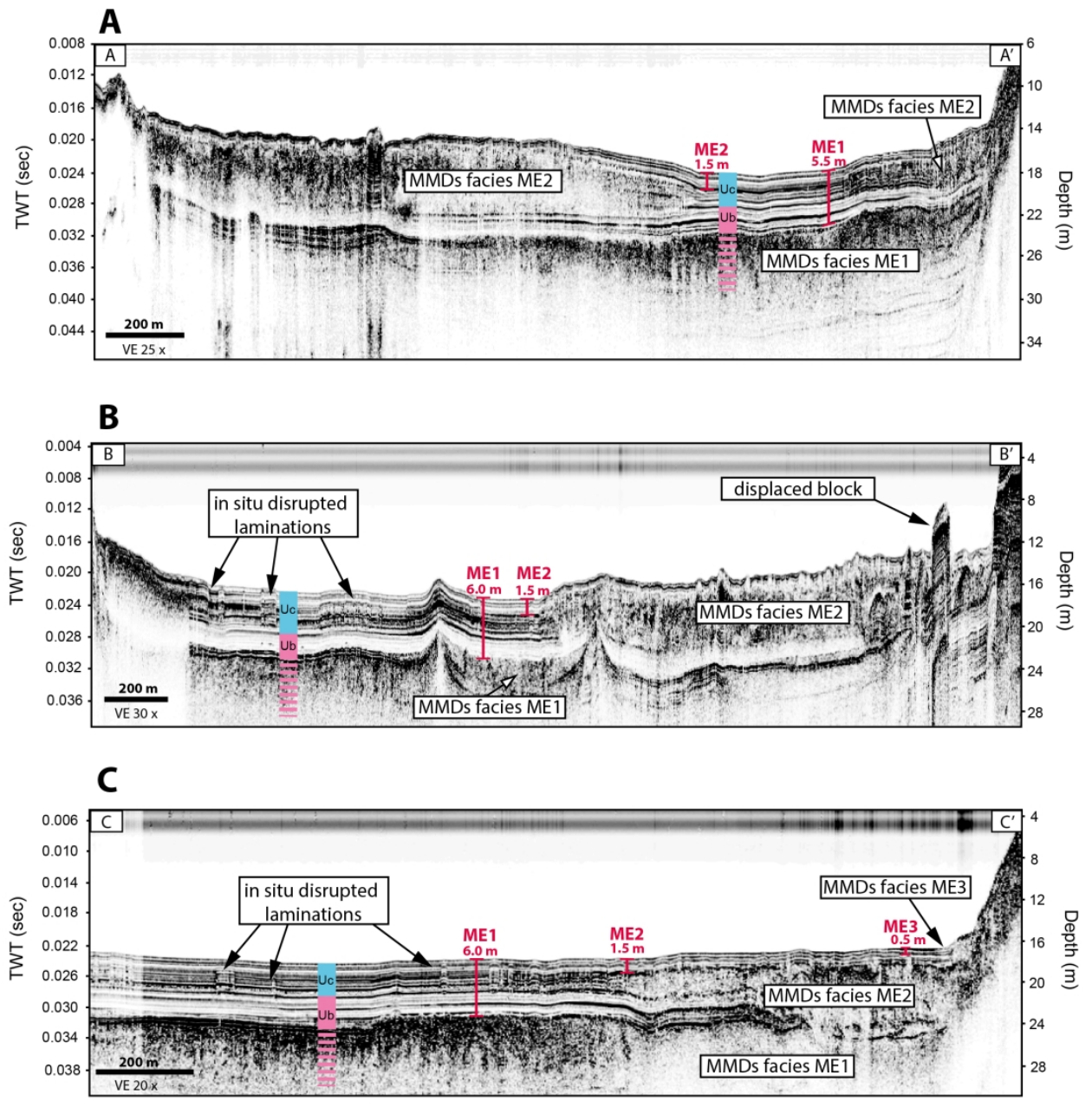

Figure 5 - Acoustic sub-bottom profiles (12 kHz) of Lake Maskinongé showing the glaciomarine (Ub) and the paraglacial and postglacial (Uc) sediments. MMDs facies are observed along three different stratigraphic levels: Event ME1 buried in Ub and Events ME2 \& ME3 in Uc. Note that the uppermost MMD facies (ME3) is only visible on profile $C$ at a depth of 0.5-1.0 m. 


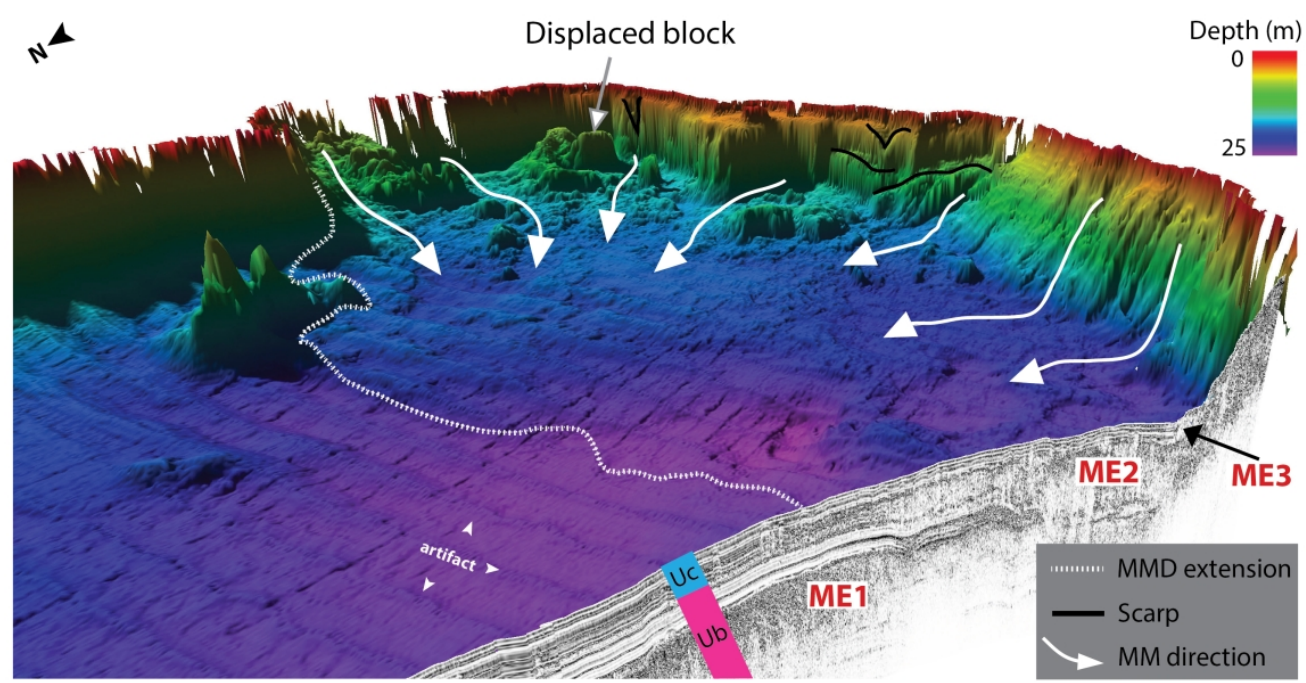

Figure 6 - 3D view of the high-resolution swath bathymetric imagery of Lake Maskinongé coupled with an acoustic profile. The hummocky topography observed on the basin floor correlate with the extent of the deposit of event ME2, suggesting that the disturbed morphology of Lake Maskinongé was caused by the second phase of mass-movement.

$258 \times 135 \mathrm{~mm}(300 \times 300 \mathrm{DPI})$ 


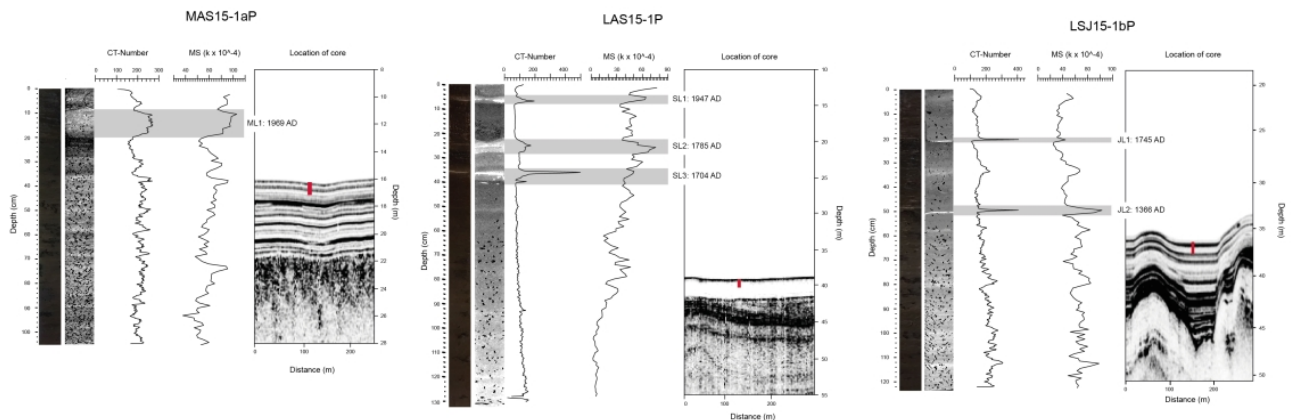

Figure 7 - Photography, CT-Scan image, CT-number, magnetic susceptibility and location on acoustic subbottom profiles of the cores sampled in Lake Maskinongé (MAS15-1aP), Aux-Sables (LAS15-1P) and StJoseph (LSJ15-1bP). Layers of high CT-number and magnetic susceptibility values are visible on the upper section of the cores and their date of deposition were inferred from each lake respective sedimentation rate.

$348 \times 123 \mathrm{~mm}(300 \times 300 \mathrm{DPI})$ 


\section{LAKE MASKINONGÉ}
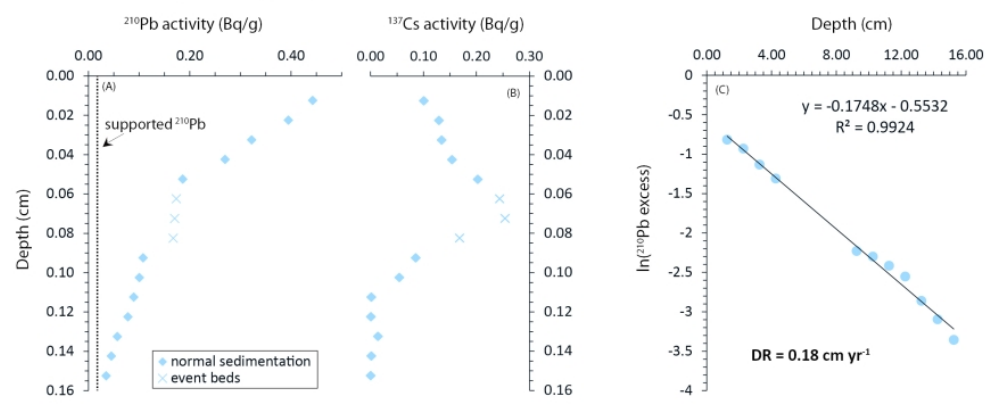

\section{LAKE-AUX-SABLES}
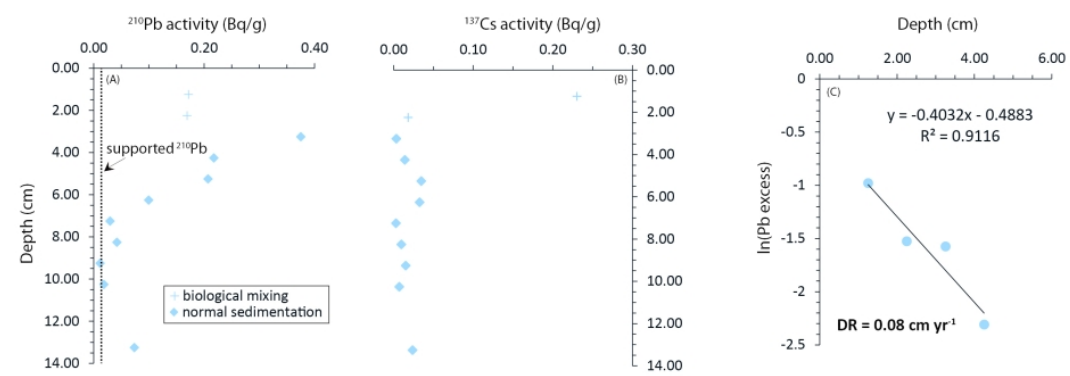

\section{LAKE ST-JOSEPH}
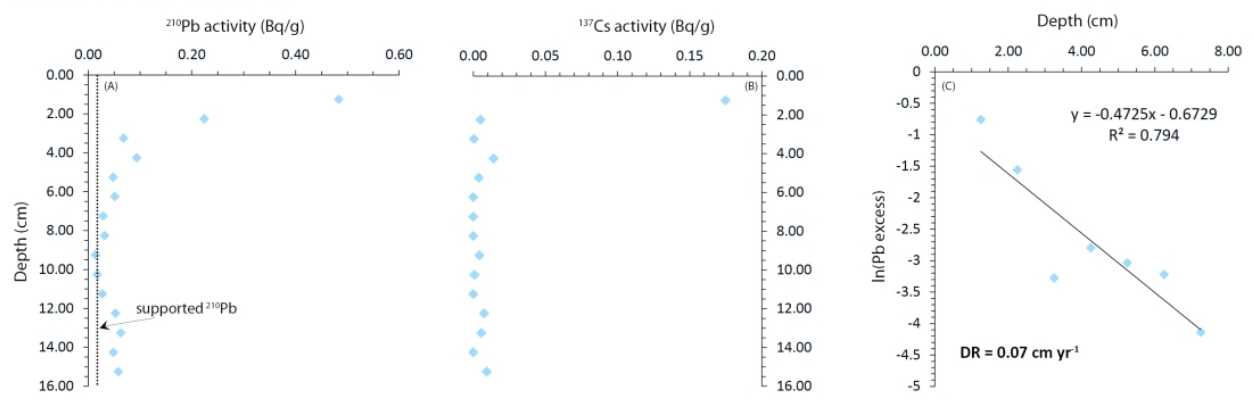

Figure $8-210 \mathrm{~Pb}(\mathrm{~A})$ and $137 \mathrm{Cs}$ (B) radiometric activity of the studied lakes. The slopes resulting from $\ln (210 \mathrm{~Pb}$ excess) vs depth indicate depositional rates of $0.18 \mathrm{~cm}$ yr-1 for Lake Maskinongé, $0.08 \mathrm{~cm}$ yr-1 for Lake Aux-Sables and $0.07 \mathrm{~cm}$ yr-1 for Lake St-Joseph. 


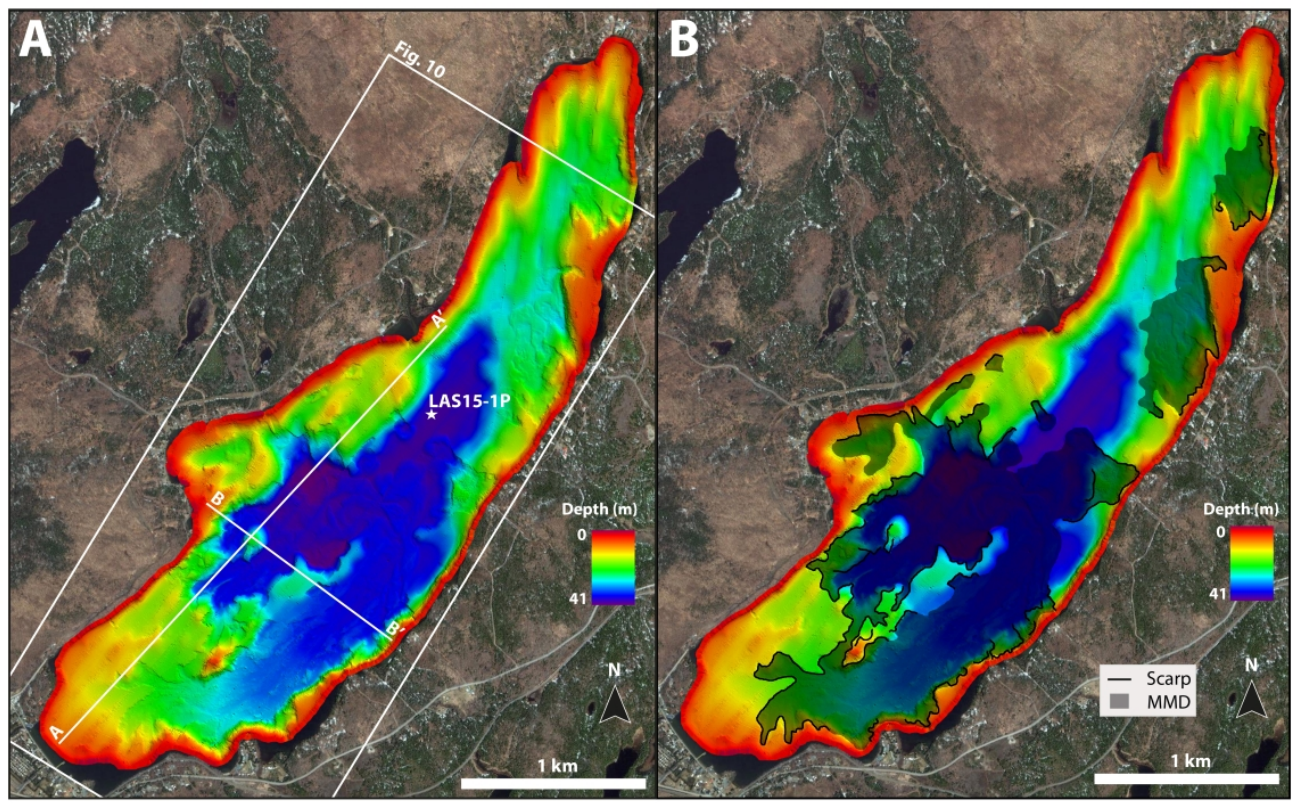

Figure 9 - A) High-resolution swath bathymetric imagery of Lake Aux-Sables with location of acoustic subbottom profiles and coring site; B) Geomorphological map of the lake showing disturbed basin morphologies: wide MMDs and numerous headwall scarps.

$431 \times 268 \mathrm{~mm}(300 \times 300 \mathrm{DPI})$ 


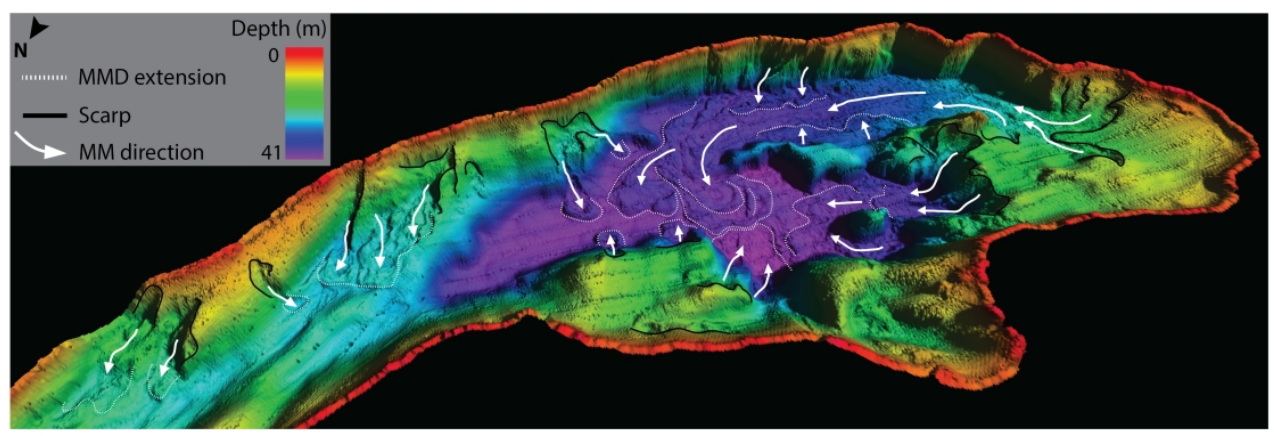

Figure $10-3 \mathrm{D}$ view of the high-resolution swath bathymetric imagery of Lake Aux-Sables showing the direction of flow of mass-movements and the extent of their deposits on the basin floor.

$303 \times 104 \mathrm{~mm}(300 \times 300$ DPI) 

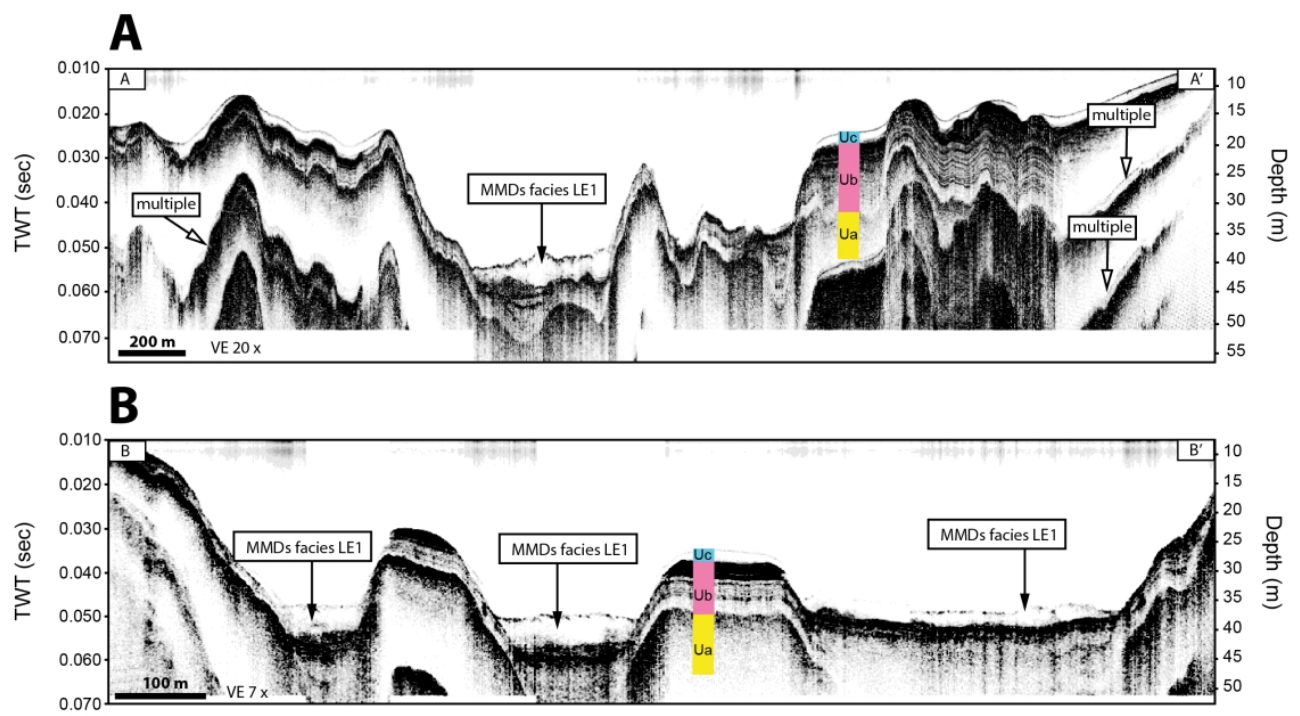

Figure 11 - Acoustic sub-bottom profiles $(3.5 \mathrm{kHz})$ of Lake Aux-Sables showing the ice-contact (Ua), the glaciomarine (Ub) and the paraglacial and postglacial (Uc) sediments. Recent MMDs facies are observed in Uc on both profiles.

$216 \times 119 \mathrm{~mm}$ ( $300 \times 300$ DPI) 


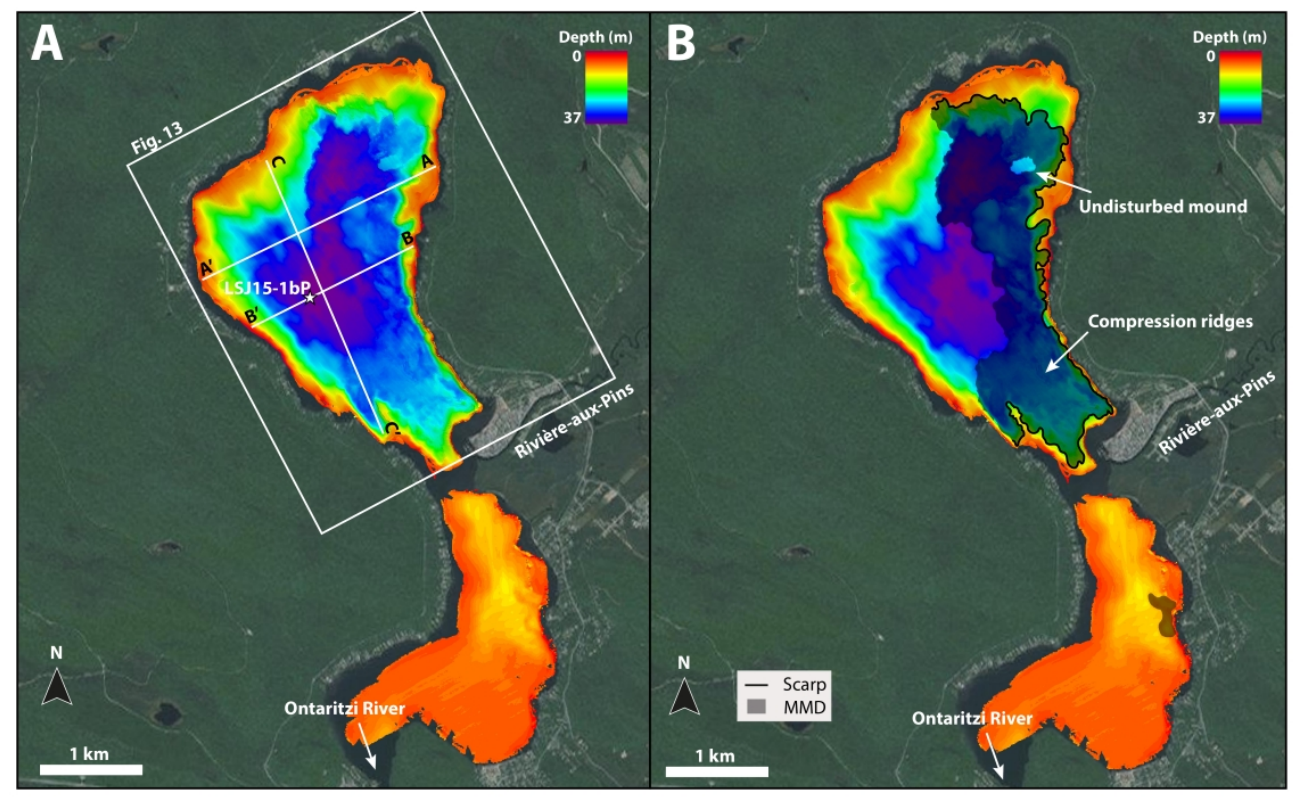

Figure 12 - A) High-resolution swath bathymetric imagery of Lake St-Joseph with location of acoustic subbottom profiles and coring site; B) Geomorphological map of the lake showing disturbed basin morphologies: wide MMD, headwall scarps, an undisturbed mound and compression ridges.

$440 \times 272 \mathrm{~mm}(300 \times 300 \mathrm{DPI})$ 


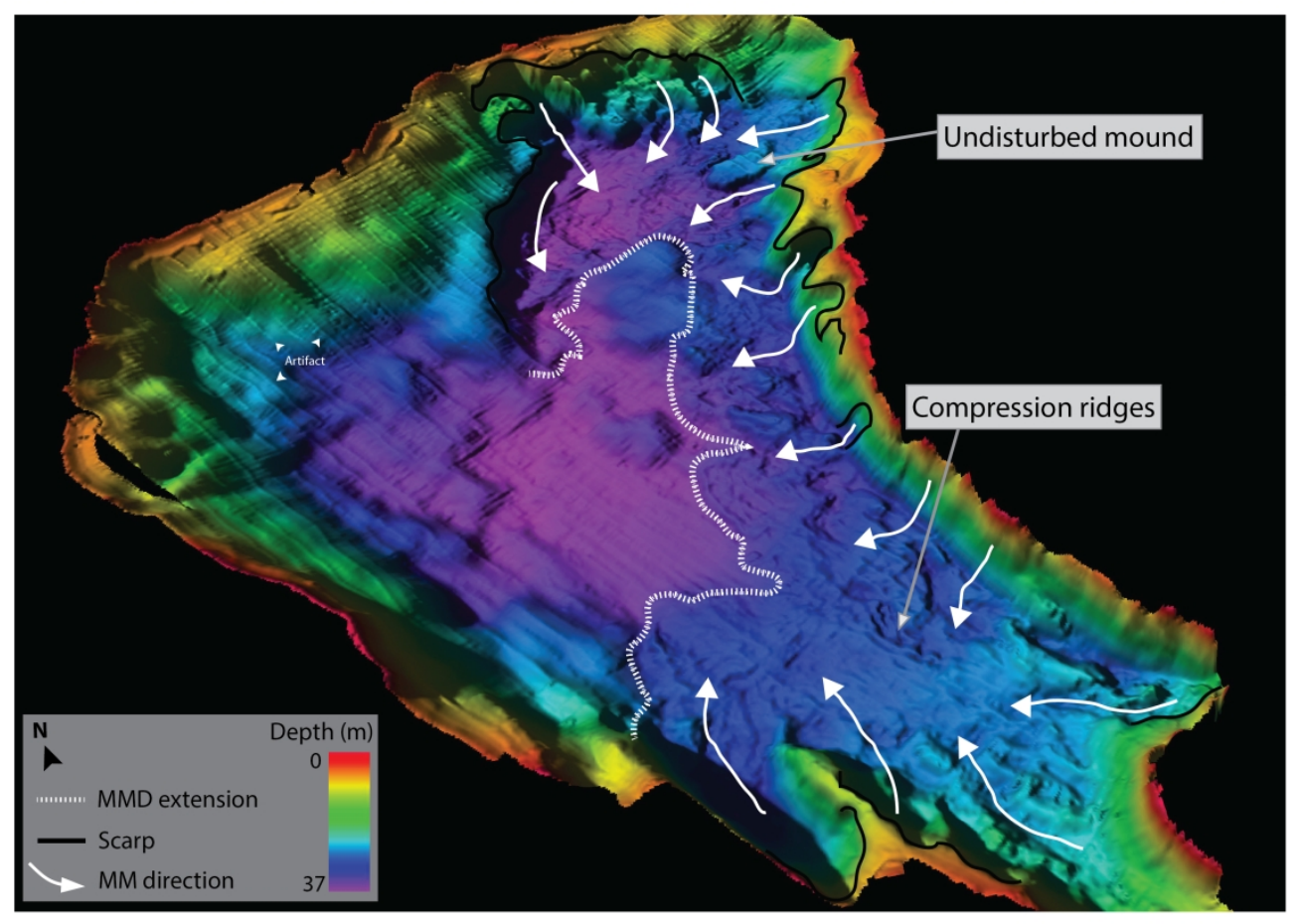

Figure $13-3 D$ view of the high-resolution swath bathymetric imagery of Lake St-Joseph showing the direction of flow of mass-movement and the extent of its deposit. Compression ridges are visible in zone of frontal thrusting.

$279 \times 199 \mathrm{~mm}(300 \times 300 \mathrm{DPI})$ 

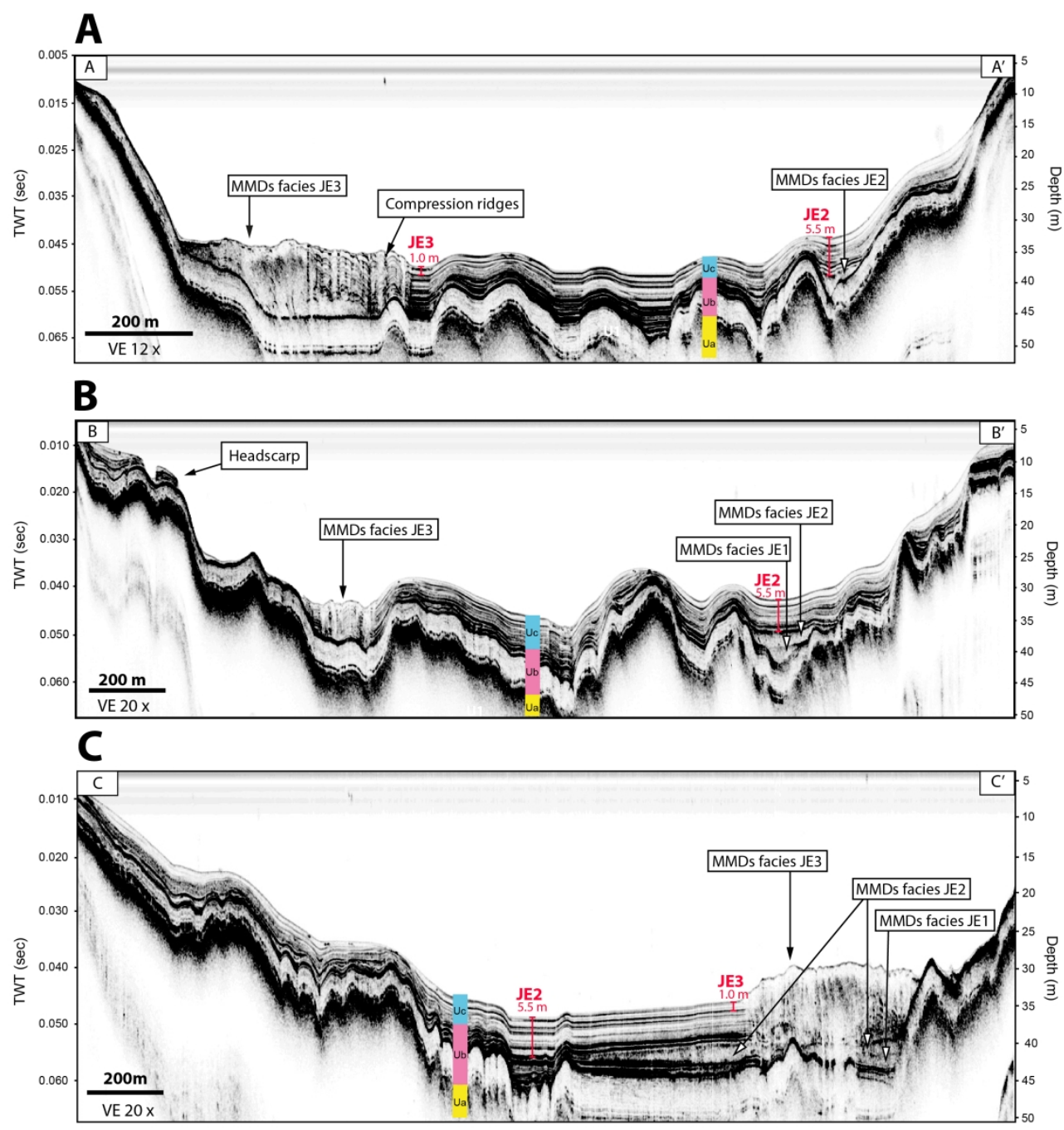

Figure 14 - Acoustic sub-bottom profiles $(12 \mathrm{kHz}$ ) of Lake St-Joseph showing the ice-contact (Ua), the glaciomarine ( $\mathrm{Ub}$ ) and the paraglacial and postglacial (Uc) sediments. MMDs facies are observed along three different stratigraphic levels: Events JE1 and JE2 buried in Ub and Event JE3 in Uc. 